\title{
KINGPIN APPROACHES TO FIGHTING CRIME AND COMMUNITY VIOLENCE: EVIDENCE FROM MEXICO'S DRUG WAR
}

\author{
Jason M. Lindo \\ María Padilla-Romo \\ Working Paper 21171 \\ http://www.nber.org/papers/w21171
NATIONAL BUREAU OF ECONOMIC RESEARCH
1050 Massachusetts Avenue
Cambridge, MA 02138

May 2015

Padilla-Romo gratefully acknowledges support from the Private Enterprise Research Center at Texas A\&M University. The views expressed herein are those of the authors and do not necessarily reflect the views of the National Bureau of Economic Research.

NBER working papers are circulated for discussion and comment purposes. They have not been peerreviewed or been subject to the review by the NBER Board of Directors that accompanies official NBER publications.

(C) 2015 by Jason M. Lindo and María Padilla-Romo. All rights reserved. Short sections of text, not to exceed two paragraphs, may be quoted without explicit permission provided that full credit, including (C) notice, is given to the source. 
Kingpin Approaches to Fighting Crime and Community Violence: Evidence from Mexico's Drug War

Jason M. Lindo and María Padilla-Romo

NBER Working Paper No. 21171

May 2015, Revised June 2015

JEL No. I18,K42,O12

\begin{abstract}
This study considers the effects of the kingpin strategy, an approach to fighting organized crime in which law-enforcement efforts focus on capturing the leaders of criminal organizations, on community violence in the context of Mexico's drug war. Newly constructed historical data on drug-trafficking organizations' areas of operation at the municipality level and monthly homicide data allow us to control for a rich set of fixed effects and to leverage variation in the timing of kingpin captures to estimate their effects. This analysis indicates that kingpin captures have large and sustained effects on the homicide rate in the municipality of capture and smaller but significant effects on other municipalities where the kingpin's organization has a presence, supporting the notion that removing kingpins can have destabilizing effects throughout an organization that are accompanied by escalations in violence.
\end{abstract}

Jason M. Lindo

Department of Economics

Texas A\&M University

4228 TAMU

College Station, TX 77843

and NBER

jlindo@econmail.tamu.edu

María Padilla-Romo

Department of Economics

Texas A\&M University

mpadilla@econmail.tamu.edu 


\section{Introduction}

The two main reasons for waging war on drugs are to reduce societal costs associated with drug abuse and to reduce societal costs associated with the drug trade. The former includes effects on health, productivity, violent behavior, and broader impacts on health care and public assistance programs. The latter includes violence involved with the enforcement of contracts and turf battles, corruption, and activity in related "industries" that are detrimental to welfare including protection rackets, human smuggling, kidnapping, prostitution, weapons trafficking, theft, etc. ${ }^{1}$ Naturally, the relative importance of these costs depends on many factors, including the types of drugs involved, the level and spatial distribution of demand, and the organization of the supply network. ${ }^{2}$ Correspondingly, there is significant heterogeneity in the approaches that have been used to wage war on drugs. Demand-side approaches take the form of prevention efforts, treatment for abusers, and increases in the cost of abuse through enforcement efforts and punishment. Supply-side approaches, on the other hand, focus on disrupting operations by way of confiscation of drugs and guns, targeting precursors, and arresting and punishing those involved in the drug trade. Given resource constraints, policy-makers have to consider which of these policies to use and how intensely to use them, highlighting the importance of understanding their costs and benefits. Towards this end, this paper considers the effects of a particular supply-side approach that has played a prominent role in Mexico's drug war-the targeting of high-ranked members of criminal organizations, also known as the "kingpin strategy" - on community violence.

To put this study into context, it is important to note that most of the existing research in this area focuses on the effects of drug-related interventions on drug abuse in "downstream markets." For example, researchers have shown that the Taliban stamping out poppy production reduced heroin use in Australia (Weatherburn et al. 2003), that the effect of Plan Colombia on the supply of Cocaine to the United States was relatively small (Mejía and Restrepo 2013), that reductions in methamphetamine availability in the

\footnotetext{
${ }^{1}$ See Miron (1999) for an in-depth discussion of the manner in which black markets can promote violence and an empirical analysis of drug and alcohol prohibition enforcement in the United States that supports this view.

${ }^{2}$ For example, the societal costs associated with the drug trade are most important in areas heavily involved in the illegal production and distribution of drugs to be consumed elsewhere.
} 
United States in the mid-1990s reduced drug-related harms (Cunningham and Liu 2003; Dobkin and Nicosia 2009; Cunningham and Finlay 2013), that US state laws limiting the availability of Pseudoephedrine have not changed methamphetamine consumption (Dobkin, Nicosia, and Weinberg 2013) nor have graphic advertising campaigns (Anderson 2010), and that substance-abuse treatment availability reduces mortality (Swensen 2015). In contrast, relatively little is known about the causal effects of "upstream interventions" on "upstream communities," i.e., the effects of interventions on outcomes in areas where production, distribution, and their associated costs are most relevant. The two studies that speak most directly to this specific issue are Angrist and Kugler (2008), which shows that exogenous shocks to coca prices increase violence in rural Colombian districts as groups fight over additional rents and Dell (2015), which shows that drug-trade crackdowns in Mexico driven by PAN mayoral victories increase drug-trade-related homicides. ${ }^{3}$

This paper contributes to this literature by considering the effects of the kingpin strategy, which has featured prominently in Mexico's war on drugs. Proponents of the kingpin strategy argue that removing a leader weakens an organization through its effect on its connections, its reputation, and by creating disarray in the ranks below, and that this may in turn reduce the organization's level of criminal activity. Detractors, however, point out that this strategy may increase violence as lower ranked members maneuver to succeed the eliminated leader and rival groups attempt to exploit the weakened state of the organization. Given sound logic underlying arguments in favor of and against the kingpin strategy, there is a clear need for empirical research on the subject. That said, there are two main empirical challenges to estimating the effect of the kingpin strategy that are difficult to overcome. First, policies targeting organized crime are almost always multifaceted, involving the simultaneous use of various strategies. Mexico's war on drugs is no exception - it also involved various approaches implemented at various times with varying degrees of intensity, which we discuss in greater detail in the next section. The second main challenge is that the capture of a kingpin is fairly rare because, by definition, they are small in number. As a result, establishing compelling evidence on the effect of eliminating kingpins in some sense requires a series of case studies.

\footnotetext{
${ }^{3}$ In related work, Mejía and Restrepo (2013) estimate the causal effect of the drug trade on violence using variation in the prominence of the drug-trade in Colombian municipalities based on land suitability for coca cultivation.
} 
This study attempts to overcome these challenges by exploiting variation in the timing with which different Mexican DTOs had their leaders captured during Mexico's drug war and by using detailed data on the geographic distribution of DTOs over time (based on Coscia and Rios (2012)) to form different comparison groups. This approach allows us to abstract away from the effects of broader policies and shocks (at the national and/or state level) and to conduct several ancillary analyses to guide our interpretation of the results. ${ }^{4}$

We find that the capture of a DTO leader in a municipality increases its homicide rate by $80 \%$ and that this effect persists for at least twelve months. Consistent with the notion that the kingpin strategy causes widespread destabilization throughout an organization, we also find significant effects on other municipalities with the same DTO presence. In particular, we find a significant short-run effect (30\% 0-6 months after capture) that dissipates over time for neighboring municipalities with the same DTO presence and an effect that is immediately small but grows over time (18\% 12+ months after capture) for more-distant municipalities with the same DTO presence. We find little evidence of any effect on neighboring municipalities where the captured leader's DTO did not have a presence.

Several additional pieces of evidence support a causal interpretation of these main results. First, there is no indication that homicides deviate from their expected levels prior to a kingpin's capture, suggesting that the main results are not driven by the sorts of efforts that might precede a capture such as the mobilization of troops into an area. We also show that the main results are driven by effects on the individuals most likely to be directly involved in the drug trade: males and, more specifically, working-age males. In an additional effort to show that the main results are not simply reflecting an increase in propensities to engage in violence that coincides with captures in the relevant municipalities, we demonstrate that domestic violence and infant mortality do not respond to these events. Lastly, we present

\footnotetext{
${ }^{4}$ Our study was conducted in parallel with Calderón et al. (forthcoming), which also considers the effects of kingpin captures during Mexico's war on drugs on homicides in the municipality of capture and its neighboring municipalities. A major distinguishing feature of our study is its use of detailed data on the geographic distribution of DTOs over time, which allows us to form different comparison groups, to distinguish between neighbors under the same DTO influence and those not under the same DTO influence, and to consider spillover effects of captures onto non-neighboring municipalities that are under the same DTO influence. Calderón et al. (forthcoming) use synthetic control approaches to form comparisons and additionally considers effects on areas of particular strategic importance. Another important difference is that we focus solely on the first kingpin capture from each DTO, for reasons discussed in Section 4, while Calderón et al. (forthcoming) consider all kingpin captures.
} 
evidence that operations themselves do not increase homicides in an analysis of the first major operations of the war on drugs.

The remainder of the paper is organized as follows. In the next section, we provide background on Mexico's drug war, including a discussion of the events that precipitated it, and the relevant DTOs. We then discuss our data and empirical strategy in sections 3 and 4, respectively. Section 5 presents a graphical analysis, the main results, and supporting analyses. Lastly, Section 6 discusses the results and concludes.

\section{Background}

\subsection{Drug-trafficking in Mexico}

In many ways, Mexico is ideally situated for producing and trafficking drugs. In addition to having a climate that allows for the growth of a diverse set of drugs, it shares a border with the world's biggest consumer of drugs, the United States. Drug trafficking has also been able to flourish in Mexico as a result of corruption and weak law enforcement. The first DTOs were protected by the government, which designated the areas in which each DTO would carry out their illegal activities. In the 1980s, former police officer Miguel Ángel Félix Gallardo - together with Rafael Caro Quintero and Ernesto Fonseca Carrillo-founded the first Mexican Cartel: the Guadalajara Cartel. ${ }^{5}$ After the incarceration of his partners in 1985, Félix Gallardo kept a low profile and decided to divide up the areas in which he operated. ${ }^{6}$ According to Grayson (2014), the government and the DTOs had unwritten agreements that "DTO leaders respected the territories of competitors and had to obtain crossing rights before traversing their turfs...criminal organization[s] did not sell drugs in Mexico, least of all to children... and prosecutors and judges would turn a blind eye to cooperative criminals."

In the 1990s, however, the environment became less stable as Guadalajara's DTO splin-

\footnotetext{
${ }^{5}$ In addition with his connections with the Mexican government, Félix Gallardo was the first Mexican drug trafficker to make connections with Colombian cartels, particularly he established a solid relation with Pablo Escobar (leader of the Medellín Cartel).

${ }^{6}$ Joaquín Guzmán Loera and Ismael Zambada García were given the pacific coast area, the Arellano Félix brothers received the Tijuana corridor, the Carrillo Fuentes family got the Ciudad Juárez corridor, and Juan García Abrejo received the Matamoros corridor.
} 
tered into four separate DTOs ${ }^{7}$ and the Institutional Revolutionary Party (PRI) lost political power (Astorga and Shirk 2010). Morales (2011) describes the late 1990s and early 2000s as a period in which the DTOs became more independent, going from a regimen of political subordination to one of direct confrontation to dispute the control of territory. In late 2005, a new DTO - La Familia - was established in the state of Michoacán followed by a wave of violence. $^{8}$ At the beginning of the war on drugs there were five DTOs (or alliances of DTOs), Sinaloa/Beltrán-Leyva, Gulf, Tijuana, La Familia, and Juárez.

\subsection{The War on Drugs}

As shown in Panel A of Figure 1, the homicide rate in Michoacán grew dramatically between 2005 and 2006. That said, the national homicide rate continued to be extremely stable at 0.8 per 100,000 residents per month (Figure 1, Panel B). Nonetheless, eleven days after the beginning of his term, the newly elected President Felipe Calderón declared war on the DTOs on December 11, 2006, citing the increase in violence in Michoacán as the last straw. While pundits highlighted his desire to have significant reform associated with his presidency and the fact that he was born and raised in Michoacán, his stated reasons for initiating the war was a concern "about the growth of drugs-related violence and the existence of criminal groups trying to take over control of entire regions." 9 Calderón's strategy mainly consisted in a frontal attack led by members of the army, the navy, and the federal police seeking the eradication of crops, the confiscation of drugs and guns, and the incarceration or killing of high ranked drug traffickers (the kingpin strategy). The first operation took place in Michoacán on December 11, 2006, where more than 5000 army and federal police elements were deployed, and subsequent operations followed in other parts of the country.

Mexico's war on drugs was initially viewed as a great success. As shown in Figure 2, plotting data from 2001 to 2010, the national homicide rate dropped sharply in January 2007. The homicide rate jumped back up to 0.72 in March — not quite to its earlier level-

\footnotetext{
${ }^{7}$ After the arrest of Félix Gallardo in 1989 and his transfer to a the maximum security prison La Palma in Mexico state, the leaders of the designated areas became independent and founded the second generation of cartels (Sinaloa, Tijuana, Juárez, and Gulf).

${ }^{8}$ La Familia DTO is the metamorphosis of La Empresa which was a former branch of the Gulf Cartel.

${ }^{9}$ Financial Times interview, conducted January 17, 2007.
} 
and then held steady for the following 9 months. Then, at the beginning of 2008 in a clear break from trend, the homicide rate started to climb. It would continue to climb for several years, reaching a level 150\% higher than the pre-drug-war rate at the end of 2010 .

This dramatic increase in violence in Mexico has drawn the attention of researchers from different disciplines trying to explain its causes - most attribute this increase in violence to Calderón's war on drugs. Different researchers have focused on the role of the deployment of federal troops all across the country (Escalante 2011, Merino 2011), the expiration of the U. S. Federal Assault Weapons Ban in 2004 (Chicoine 2011, Dube et al.. 2012), the increase of cocaine seizures in Colombia (Castillo et al. 2012, Mejía 2013), and the increased effort to enforce law initiated by the National Action Party (PAN) mayors (Dell, Forthcoming).

Our research is motivated by the observation that the escalation of violence began in January 2008, which was the month in which the first cartel leader was captured during the war on drugs (Alfredo Beltrán Leyva). Naturally, many other things were going on in Mexico and around the world at the same time, necessitating a more rigorous consideration to be able to draw any strong conclusions about the effects of Mexico's kingpin strategy. In order to conduct such an analysis, we make use of newly constructed data on the geographic distribution of DTOs over time - in conjunction with several other data sets - to consider the first captures of kingpins associated with each of the five DTOs in operation at the beginning of the war on drugs. These data and the associated identification strategy are described in the next sections.

\section{Data}

Our analysis brings together data from several sources that ultimately yields a data set at the municipality-month level, spanning January 2001 through December 2010. Our primary outcome variable is based on monthly homicides at the municipality level, constructed using the universe of death certificates from the vital statistics of the National Institute of Statistics and Geography (INEGI) ${ }^{10}$ In order to put these data into per capita rates, we use estimated

\footnotetext{
${ }^{10}$ Less than one percent of death certificates with homicide as the presumed cause of death are missing the municipality of occurrence. These observations are not used in our analysis.
} 
municipality population counts from the National Council of Population (CONAPO) and El Colegio de México (COLMEX), which are based on projections from the Census of Population and Housing. While we note that drug-related homicides are available from December 2006 to October 2011, we do not use these data out of concern for the endogeneity of homicides being classified as "drug related" or "not drug related."

Our information on kingpin captures are from a compendium of press releases of the Army (SEDENA), the Navy (SEMAR), and the Office of the Attorney General (PGR). While these press releases contain a wealth of additional information, we focus on the timing of the first capture of a leader or lieutenant from each of the DTOs during the war on drugs. To put into perspective the types of kingpins we are considering, as the name implies, leaders are at the very highest level of the DTO. Lieutenants are immediately below leaders in the DTO organization. As a practical matter, we classify an event as a capture of a DTO leader when a press release indicates that the individual was a head (or one of the heads) of a DTO and identify an event as a capture of a DTO lieutenant when a press release indicates that the individual was a leader of a DTO in some state or region. We do not consider events in which the press release indicates that the individual was a leader only in a particular municipality, indicating that the individual was likely a plaza boss.

As shown in Table 1, there is significant variation in the timing with which high-level kingpins were captured for the five DTOs in operation at the beginning of the war on drugs. The first took place on August 29th, 2007-eight months after the war on drugs beganwhen Juan Carlos de la Cruz Reyna, a lieutenant in the Gulf Cartel was captured. The first other four DTOs (Sinaloa-Beltrán-Leyva, Tijuana, Juárez, and La Familia) had top level leaders captured at various times between January and December of $2008 .{ }^{11}$

We use newly available historical data on the municipalities of operation for each DTO, the construction of which is described in detail in Coscia and Rios (2012). Briefly, the data was constructed using a MOGO (Making Order using Google as an Oracle) framework for selecting the most reliable subset of web information to collect information on relationships between sets of entities (DTOs and municipalities in this case). It uses indexed web content (e.g., online newspapers and blogs) and various queries to identify DTOs' areas of operation

\footnotetext{
${ }^{11}$ Sinaloa and Beltrán-Leyva DTOs were allied before the drug war commenced.
} 
at the municipality level between 1990 and 2010. ${ }^{12}$ To avoid concerns about endogeneity, we define areas of operation using only data before the war on drugs began (2001-2006). Moreover, we take a conservative approach and specify that a DTO had a presence in a municipality if the municipality was an "area of operation" for the DTO in any of these six years. Figure 3 maps out the distribution of the DTOs based on this definition. One important takeaway from this figure - which we exploit in our empirical analysis - is that a large share of Mexico has no DTO presence (or a DTO presence that is too weak or inactive to be picked up using Coscia and Rios' approach).

\section{Empirical Strategy}

While we begin our analysis of the effects of the kingpin captures homicides with a series of graphical comparisons, our main results are based on a generalized difference-in-differences approach. In particular, we estimate the effects of kingpin captures using the following regression model:

$$
\ln H_{m t}=D_{m t} \delta+\alpha_{m}+\gamma_{t}+X_{m t} \beta+u_{m t}
$$

where $\ln H_{m t}$ is the natural log of the homicide rate in municipality $m$ at time $t$; $D_{m t}$ is a set of indicator variables reflecting whether a kingpin relevant to the municipality has been captured in 0-5 months ago, 6-11 months ago, or 12+ months ago; $\alpha_{m}$ are municipality fixed effects; $\gamma_{t}$ are month-by-year fixed effects; $X_{m t}$ can include time-varying municipality controls; and $u_{m t}$ is an error term. ${ }^{13}$ As such, the estimates are identified by comparing changes in violence among affected and non-affected municipalities using variation in the timing with which different municipalities are affected because of their links to different DTOs (and having no link to any DTO). This approach allows us to avoid biases that would otherwise be introduced by fixed differences across municipalities and by the effects of any shocks or interventions that are common across municipalities. The fact that we have municipalities associated with different DTOs who have kingpins captured at different times and we also have municipalities without any DTO presence allows us to additionally

\footnotetext{
${ }^{12}$ Such data was previously only available to the research community at the state level.

${ }^{13}$ We add one to the homicide count to avoid missing values.
} 
control for the effects of the war on drugs that are common to municipalities with a DTO presence, which we accomplish by including variables for $0-5,6-11$, and $12+$ months after the beginning of the war interacted with an indicator for the presence of a DTO in the municipality. We can also control for additional spatial heterogeneity by including state-byyear fixed effects in the model.

Two main aspects of the empirical analysis that we have yet to discuss in detail are: how to define whether a kingpin capture is "relevant to a municipality" and what sorts of captures are considered. We define a kingpin capture as being "relevant to a municipality" in four different ways to allow for treatment effect heterogeneity. In particular, we separately estimate effects of a kingpin capture on the municipality of capture, neighboring municipalities where the captured kingpin's DTO had a presence, other neighboring municipalities, and non-neighboring municipalities where the captured kingpin's DTO had a presence. As described in the previous section, our analysis of "kingpins" focuses DTO leaders and lieutenants, i.e., those at the very top level of the organization and those who control a state or region. We further restrict attention to the first capture of a kingpin for each DTO during the war on drugs. We do so out of concern for the endogeneity that would be introduced when the capture of a kingpin affects the outcome while also increasing the probability of the capture of subsequent kingpins. By focusing instead on the effects of an initial capture, our estimates will reflect the effect of a kingpin capture on outcomes that is inclusive of the effects driven by subsequent captures.

We note that standard-error estimation is not straightforward in this context. While we are evaluating a panel of municipalities, there may be reason to cluster standard-error estimates at some higher level(s) because different municipalities may have correlated shocks to outcomes not captured by our model. In some sense, because the source of variation is at the DTO level, it may be preferable to allow the errors to be correlated across municipalities when they share the presence of the same DTO. However, with only five DTOs, this would lead to problems associated with too few clusters. As a compromise, we instead cluster on DTO-combinations, which leverages the fact that there are some municipalities where two or three municipalities have a presence. ${ }^{14}$ We additionally cluster on states to allow for some

\footnotetext{
${ }^{14} 2,224$ municipalities have no DTO presence, 181 have one, 43 have two, and only six have three.
} 
spatial correlation in the errors that might occur naturally or through policies implemented at the state level, following the approach to multi-way clustering described in Cameron, Gelbach, and Miller (2011). ${ }^{15}$

\section{Results}

\subsection{Graphical Evidence of the Effects of Kingpin Captures}

Before presenting the results of the econometric analysis described above, in this section we present graphical evidence. To begin, Figure 4 plots the homicide rate over time separately for counties with a DTO presence before the war on drugs and those that did not have such a presence. This figure shows that municipalities with a DTO presence had higher - but not much higher-homicide rates than municipalities without a DTO presence in the six years leading up to the war on drugs. Moreover, they tracked one another quite closely. Perhaps most importantly, they even tracked one another after the beginning of the war on drugsboth dipping immediately before returning to close to their earlier levels - which provides support for using municipalities without a DTO presence as a meaningful comparison group for the purpose of attempting to separate the effects of kingpin captures from the effects of other aspects of the war on drugs. Twelve months after the beginning of the war on drugs, however, the two series began to diverge from one another in a dramatic way. While the capture of Alfredo Beltrán Leyva, leader of the Beltrán Leyva Cartel, would appear to be the most salient event to happen around this time that would disproportionately affect municipalities with a DTO presence, we cannot rule out other explanations such as a lagged effect of earlier aspects of the war on drugs. One explanation that we can rule out is that the war on drugs did not begin in earnest until this time - several major operations took place in 2007 which lead to the seizure of 48,042 $\mathrm{Kg}$ of cocaine, 2,213,427 $\mathrm{Kg}$ of marijuana, and $317 \mathrm{Kg}$ of heroin, significantly more than the amounts seized in the subsequent years. ${ }^{16}$

Across the five panels of Figure 5, we take a more systematic look at how homicide rates

\footnotetext{
${ }^{15}$ This approach leads to somewhat more conservative standard-error estimates than clustering only on states, only on DTO combinations, or only on municipalities.

${ }^{16}$ Third Calderón's Government Report (Tercer Informe de Gobierno, 2009).
} 
changed over time in municipalities with a DTO presence relative to those without in relation to kingpin captures. In panels A and B, we plot time series that focus on municipalities with the presence of DTOs whose first captured "kingpin" was a leader at the highest level of the organization. In particular, in Panel A we plot the homicide rate over time for municipalities where Sinaloa or Beltrán Leyva (allies) had a presence prior to the war on drugs in addition to the homicide rate for municipalities with no DTO presence for comparison. Consistent with Figure 4, this figure shows that the two series tracked one another closely until the beginning of 2008 when the first kingpin from either Sinaloa or Beltrán Leyva was captured (Alfredo Beltrán Leyva). In Panel B we present similar plots but instead focus on municipalities where the Tijuana Cartel had a presence prior to the war on drugs, highlighting the point in time when it first had a leader captured in October of 2008. This plot is qualitatively similar to the one shown in Panel A in that the homicide rate in municipalities where the Tijuana Cartel had a presence and municipalities with no DTO presence track one another closely in the years preceding the war on drugs and after the start of the war on drugs until the Tijuana Cartel had a leader captured.

In panels $\mathrm{C}$ through $\mathrm{E}$ we plot similar figures for the first kingpins captured during the war on drugs for the other three DTOs, noting that these kingpins were lieutenants in control of large regions as opposed to heads of the organizations. In all three panels we see homicide rates rise in municipalities with the DTO presence relative to municipalities with no DTO presence following the relevant kingpin's capture. That said, municipalities with a Gulf Cartel presence did not see an immediate rise in their homicide rates after the capture of Juan Carlos de la Cruz Reyna (a lieutenant in the organization responsible for operations in the southern part of Tamaulipas and the northern part of Veracruz ) - their homicide rates did not rise until approximately a half of a year later. In contrast, the homicide rates rose immediately - and have subsequently continued to rise - in municipalities where the Juárez Cartel had a presence after Pedro Sánchez Arras (a lieutenant in the organization responsible for operations in the northern part of Chihuahua) was captured in May of 2008. The time series for municipalities where La Familia Cartel had a presence also shows an uptick in homicides after the first capture of one of its kingpins during the war on drugs (Alberto Espinoza Barrón, the lieutenant responsible for the collection of narcotics from the Port of 
Lázaro Cárdenas). This uptick appears to have not been sustained though it is not clear due to a large degree of volatility in the homicide rate in the region.

As a whole, the evidence shown in Figure 5 supports the notion that kingpin captures escalate violence. That said, the regression-based analysis presented in the next section can address some outstanding concerns about omitted variables through the inclusion of control variables in addition to considering heterogeneous effects across different types of municipalities.

\subsection{Regression-based Evidence of the Effects of Kingpin Captures}

Columns 1 through 3 of Table 2 present our main results, based on the generalized differencein-differences model represented by Equation 1. In particular, these columns show the estimated effects of a kingpin capture over time for a municipality of capture, municipalities where a captured kingpin's DTO had a presence that do not neighbor the municipality of capture, neighboring municipalities where a captured kingpin's DTO had a presence, and other municipalities neighboring the municipality of capture. The estimates are based on models that control for municipality fixed effects and month-by-year fixed effects. Column 2 additionally controls for state-by-year fixed effects to address concerns that captures may be correlated with other state-level policy initiatives and/or shocks while Column 3 further adds controls for the effects of the war on drugs that are common to municipalities with a DTO presence by including variables for $0-5,6-11$, and $12+$ months after the beginning of the war interacted with an indicator for the presence of a DTO in the municipality.

Across these columns, we note that the estimates are somewhat sensitive to the inclusion of state-by-year fixed effects but not to the inclusion of controls for the effects of the war on drugs that are common to municipalities with a DTO presence. Regardless of the exact specification, the estimates indicate significant effects and considerable heterogeneity. In particular, the estimates reflect an immediate and sustained effect of a kingpin capture on the homicide rate in the municipality of capture of approximately $60-80 \% .{ }^{17}$ Consistent with the notion that the kingpin strategy causes widespread destabilization throughout an

\footnotetext{
${ }^{17}$ As the outcome is the log of the homicide rate, the percent effects are calculated by exponentiating the coefficient estimate - in this case 0.48 and 0.58 - and subtracting one.
} 
organization, our preferred estimates (Column 3) suggest significant short-run effects on homicide rates in municipalities where the captured kingpin's DTO had a presence that neighbored the municipality of capture: $28 \%$ 0-5 months after the capture and 17\% 6-11 months after capture. These estimates are relatively imprecise due to the limited number of municipalities contributing to the estimates, and they are only statistically significant at the 10-percent level. In contrast, the estimated effects on non-neighboring municipalities where the captured kingpin's DTO had a presence are relatively precise, indicating a significant effect in the short-run ( $7 \%$ 0-5 months following a capture) that appears to grow over time (9\% 6-11 months following a capture and 18\% 12+ months following a capture). The estimated effects on municipalities neighboring the municipality of a kingpin capture who do not share the same DTO presence are routinely negative, suggesting that kingpin captures may lead to a spatial displacement of violence; however, these estimates tend to not be statistically significant.

Columns 4 and 5 of Table 2 assess the validity of the research design by considering whether homicide rates deviate from their expected levels prior to a kingpin capture in any of these types of municipalities. These estimates are routinely close to zero and are never statistically significant, which provides support for a causal interpretation of the estimates discussed above.

\subsection{Further Analyses Supporting a Causal Interpretation of the Main Results}

Similar to our analysis verifying that there are no "effects" before a kingpin capture occurs, which would otherwise suggest that our regression model is picking up something other than the effects of kingpin captures, in Table 3 we separately consider the estimated effects on male homicide rates, female homicide rates, rates of domestic violence, and infant mortality using our preferred model. ${ }^{18}$ These estimates provide further support for a causal interpretation of our main results: they indicate that the effects are larger for males than females,

\footnotetext{
${ }^{18}$ Domestic violence data comes from administrative records of individuals arrested for the crime of domestic violence from Estadśticas Judiciales en Material Penal de INEGI. Infant mortality data is based on the same source as the homicide data described above.
} 
which is consistent with gender differences in participation in the drug trade; no effects on domestic violence, which provides reassuring evidence that the main results are not driven by idiosyncratic shocks to levels of violence coinciding with kingpin captures; and no effects on infant mortality, which provides reassuring evidence that the main results are not driven by compositional changes towards a higher-risk population in the affected municipalities.

Table 4 presents evidence along similar lines, considering effects on homicide rates for males of different age groups. These estimates indicate that the effects on males are driven by those between the ages of 15 and 59, mirroring participation rates in drug trafficking (Fairlie 2002, Vilalta and Martínez 2012). Moreover, the estimated effects on homicides rates for younger and older males tend to be close to zero and are not statistically significant any more than we would expect by random chance.

Though our main results are able to control for national and state-level policies and shocks common across areas in addition those common to municipalities with a DTO presence through the inclusion of fixed effects, a potential concern with the empirical strategy is that it might conflate the effects of kingpin captures with the effects of military operations more broadly. In order to speak to this possibility, Figure 6 considers each of the nine major state (or multi-state) operations of the war on drugs in the timeframe spanned by our data. ${ }^{19}$ In particular, each panel restricts attention to the state(s) of the operation and separately plots the homicide rate for municipalities with and without a DTO presence. Collectively, these nine panels indicate that the major operations of the drug war did not precipitate increases in homicides. The one panel (h) that does show a major uptick in homicides at the beginning of the operation is one in which a kingpin was captured soon after its start ${ }^{20}$ and the location of the next phase of Sierra Madre operation. ${ }^{21}$

Figure 7 also focuses on homicide rates as they relate to major operations of the war on drugs but instead considers municipality-level operations. Notably, all municipalities that were the target of an operation, saw dramatic rises in their homicide rates. That said, as

\footnotetext{
${ }^{19}$ The beginning dates for these operations are based on information from the fifth Calderóns Government Report (Quinto Informe de Gobierno, 2011). End dates are not specified except for Sierra Madre, Marlín, and Culiacán operations.

${ }^{20}$ Pedro Sánchez Arras, lieutenant in the Juárez Cartel, captured approximately six weeks after the Chihuahua Operation began.

${ }^{21}$ Sierra Madre operation was launched on January 7, 2007 in the states of Chihuahua, Durango, and Sinaloa.
} 
with the state level operations, there appears to be no consistent link between operations of the war on drugs and these rises - some of these municipalities saw their homicide rates begin to rise before an operation, some after, and some at around the same time.

Table 5 offers an additional check on the main results by considering the sensitivity of the estimates to the exclusion of considering any given DTO. In particular, across the columns of the table we report results systematically excluding from the analysis municipalities where the Sinaloa-Beltrán-Leyva cartels have a presence (Column 2), where the Tijuana Cartel has a presence (Column 3), where the Gulf Cartel has a presence (Column 4), where the Juárez Cartel has a presence (Column 5), and where the Familia Cartel has a presence (Column 6), respectively. This analysis is motivated by the notion that we should be less confident in the results if they are driven by any one particular kingpin's capture. The estimates are most sensitive to the exclusion of municipalities where the Sinaloa-Beltrán-Leyva and Gulf cartels have a presence, which span the most municipalities and the municipalities with the largest populations (as shown in Table 1). That said, the estimates guide us to the same conclusion regardless of whether any one DTO is not considered in the analysis - kingpin captures have large and immediate effects on the municipality of capture that are quite persistent; there are spillover effects onto other municipalities where the captured kingpin's DTO has a presence; and there are perhaps some effects on neighboring municipalities where the kingpin's DTO does not have a presence.

\section{Discussion and Conclusion}

In the preceding sections, we have estimated the effects of the first kingpin captures during Mexico's war on drugs for the DTOs that were in operation prior to the war. Newly available data on DTOs' areas of operation at the municipality level over time and monthly data on homicides allow us to control for a rich set of fixed effects and to leverage variation in the timing of kingpin captures to consider the effects on homicides in the area of capture itself in addition to other areas where the kingpin's DTO has a presence. The results of this analysis indicate that kingpin captures have large and sustained effects on the homicide rate in the

municipality of capture and smaller but significant effects on other municipalities where the 
kingpin's DTO has a presence, supporting the notion that the kingpin strategy can have destabilizing effects throughout an organization while highlighting that this does not imply a reduction in violence. Spillover effects onto municipalities neighboring the municipality of capture appear to be small and, if anything, positive (as they suggest a reduction in homicides).

These estimates offer a new lens through which we can view the dramatic increase in violence in Mexico since the beginning of the war on drugs. In particular, our estimates suggest that the kingpin captures we consider lead to an additional 11,626 homicides since 2007, or approximately 17 percent of the homicides since that time. Moreover, the effects of these kingpin captures can explain 36 percent of the 130 percent increase in the homicide rate (or approximately a quarter) between 2006 and 2010. ${ }^{22}$ An important caveat to these figures is that we use an imperfect measure of DTOs' areas of operation (based on the MOGO approach described above) and that misclassification would serve to bias our estimates towards zero - as such, they may be best thought of as estimates of the lower bound of the true effects.

While our estimates indicate that Mexico's use of the kingpin strategy caused significant increases homicides, it is important to note that its war on drugs had several objectives beyond reducing violence, including the establishing the rule of law, that need to be considered in evaluating the policy. Moreover, it remains possible that the kingpin strategy could reduce violence in the long-run in ways that have yet to be seen.

\footnotetext{
${ }^{22}$ These numbers were calculated using the regression coefficients from Column 3 of Table 2. In particular, they are based on the municipalities affected by the capture of a kingpin, multiplying its homicide rate prior to the capture by the relevant coefficient estimate for each year and adjusting for the change in its population. These calculations indicate that the capture of kingpins caused an increase in homicides of approximately 600 in 2007, 3,000 in 2008, 3,900 in 2009 and 4100 in 2010.
} 


\section{References}

Anderson, D. M. (2010): "Does Information Matter? The Effect of the Meth Project on Meth Use among Youths," Journal of Health Economics, 29, 732-742.

Angrist, J. D., And A. D. Kugler (2008): "Rural windfall or a new resource curse? Coca, income, and civil conflict in Colombia," Review of Economics and Statistics, 90(2), $191-215$.

Astorga, L., And D. A. Shirk (2010): "Drug trafficking organizations and counter-drug strategies in the US-Mexican context," Center for US-Mexican Studies.

Calderón, G., G. Robles, A. Díaz-Cayeros, and B. Magaloni (forthcoming): "The Beheading of Criminal Organizations and the Dynamics of Violence in Mexico," Journal of Conflict Resolution.

Cameron, A. C., J. B. Gelbach, and D. L. Miller (2011): "Robust Inference With Multiway Clustering," Journal of Business and Economic Statistics, 29(2), 238-249.

Castillo, J. C., D. Mejía, and P. Restrepo (2012): "Illegal drug markets and violence in Mexico: The causes beyond Calderón," Working Paper.

Chicoine, L. (2011): "Exporting the Second Amendment: U.S. Assault Weapons and the Homicide Rate in Mexico," Working Paper.

Coscia, M., And V. Rios (2012): "Knowing where and how criminal organizations operate using web content," CIKM, pp. 1412-1421.

Cunningham, J. K., And L. M. LiU (2003): "Impacts of federal ephedrine and pseudoephedrine regulations on methamphetamine-related hospital admissions," Addiction, 98(9), 1229-1237.

Cunningham, S., and K. Finlay (2013): "Parental substance use and foster care: Evidence from two methamphetamine supply shocks," Economic Inquiry, 51(1), 764-782.

Dell, M. (2015): "Trafficking Networks and the Mexican Drug War," American Economic Review, 105(6), 1738-1779.

Dobkin, C., And N. Nicosia (2009): "The war on drugs: methamphetamine, public health, and crime," American Economic Review, 99(1), 324-349.

Dobkin, C., N. Nicosia, and M. Weinberg (2014): "Are supply-side drug control efforts effective? Evaluating OTC regulations targeting methamphetamine precursors.," Journal of Public Economics, 120, 46-61.

Dube, A., O. Dube, and O. García-Ponce (2013): "Cross-Border Spillover: U.S. Gun Laws and Violence in Mexico," American Political Science Review, 107(3), 397-417.

Escalante, F. (2011): "Homicidios 2008-2009 La muerte tiene permiso," Nexos. 
FAIRLIE, R. W. (2002): "Drug Dealing and Legitimate Self-Employment," Journal of Labor Economics, 20(3), 538-537.

Grayson, G. W. (2013): The Cartels: The Story of Mexico's Most Dangerous Criminal Organizations and Their Impact on US Security. ABC-CLIO, Santa Barbara, CA.

Mejía, D., And P. Restrepo (2013): "Bushes and Bullets: Illegal Cocaine Markets and Violence in Colombia," Documento CEDE.

Merino, J. (2011): "Los operativos conjuntos y la tasa de homicidios: una medición," Nexos.

Miron, J. A. (1999): "Violence and the U.S. Prohibitions of Drug and Alcohol," American Law and Economics Review, 1(1), 78-114.

Morales-Oyarvide, C. (2011): "La Guerra Contra el Narcotráfico en México. Debilidad del Estado, Orden Local y Fracaso de una Estrategia," Aposta, 50.

Swensen, I. D. (2015): "Substance-Abuse Treatment and Mortality," Journal of Public Economics, 122, 13-30.

Vilalta, C. J., And J. M. Martinez (2012): "The making of Narco bosses: hard drug dealing crimes among Mexican students," Trends in organized crime, 15(1), 47-63.

Weatherburn, D., C. Jones, K. Freeman, and T. Makkai. (2003): "Supply control and harm reduction: lessons from the Australian heroin drought," Addiction, 98(1), 83-91. 
Figure 1

Monthly Homicide Rates Prior the Beginning of the War on Drugs

(a) Michoacán

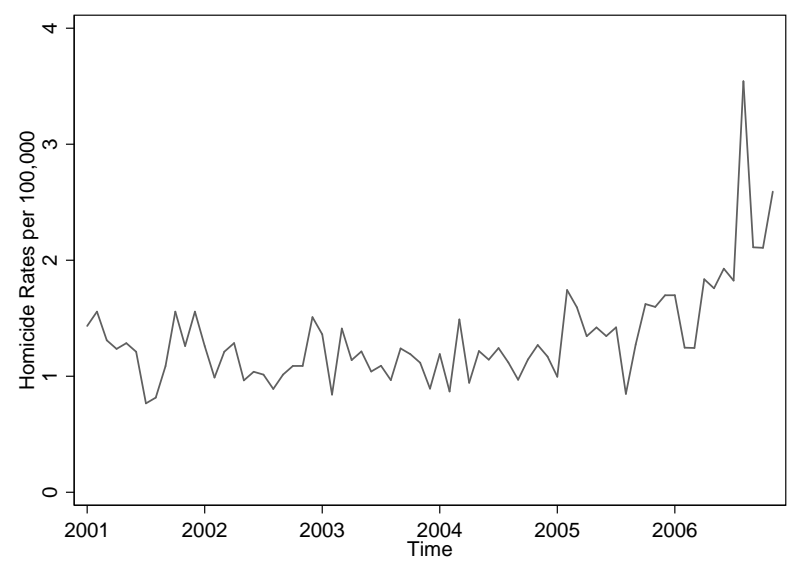

(b) National

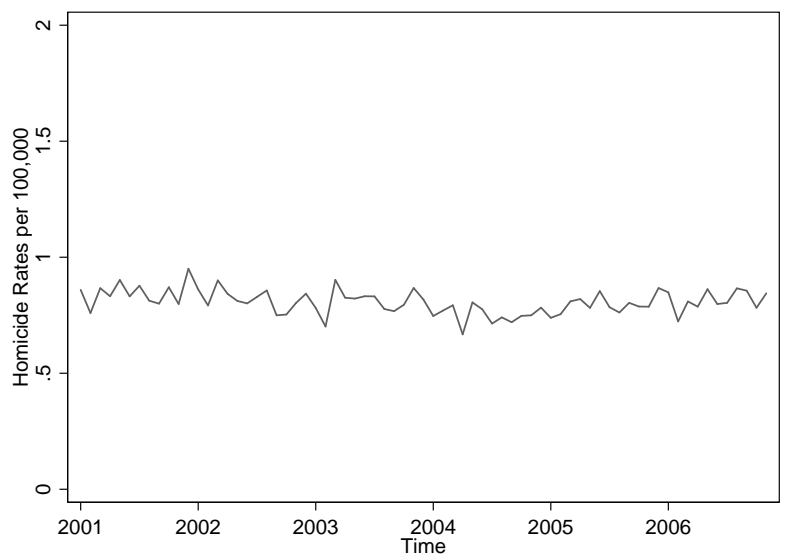

Notes: Panel A plots the homicide rate in the state of Michoacán, President Felipe Calderón's home state, leading up to his declaring war on drugs. Panel B plots the nationwide homicide rate over the same time period. These homicide rates are calculated based on the universe of death certificates from the vital statistics of the National Institute of Statistics and Geography (INEGI) and population counts from the National Council of Population (CONAPO) and El Colegio de México (COLMEX). 
Figure 2

National Homicide Rate

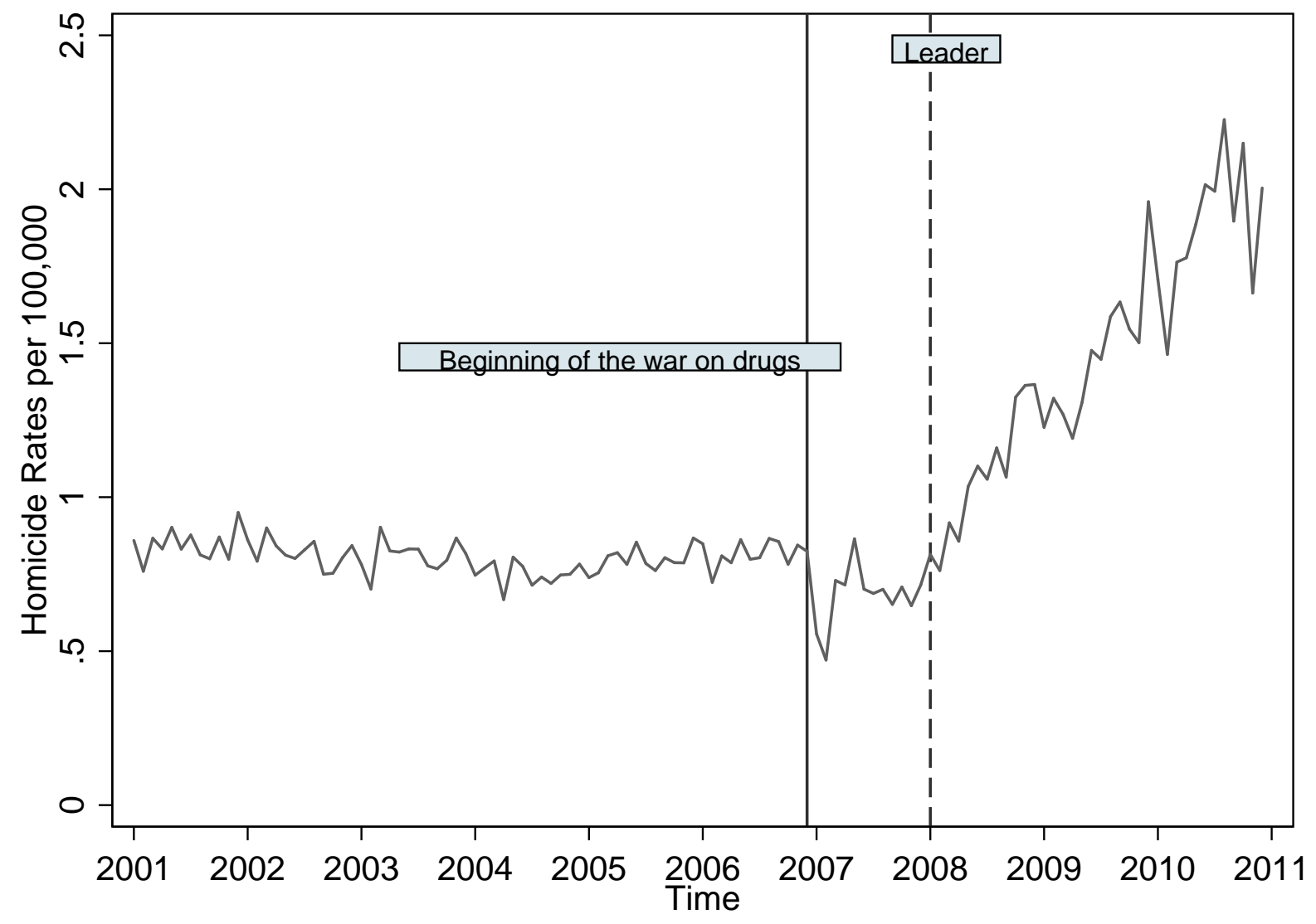

Notes: See Figure 1. Vertical lines are drawn to highlight the beginning of the war on drugs and the first capture of a DTO leader during the war on drugs. 
Figure 3

Municipalities with DTO Presence, 2001-2006

(a) Any DTO

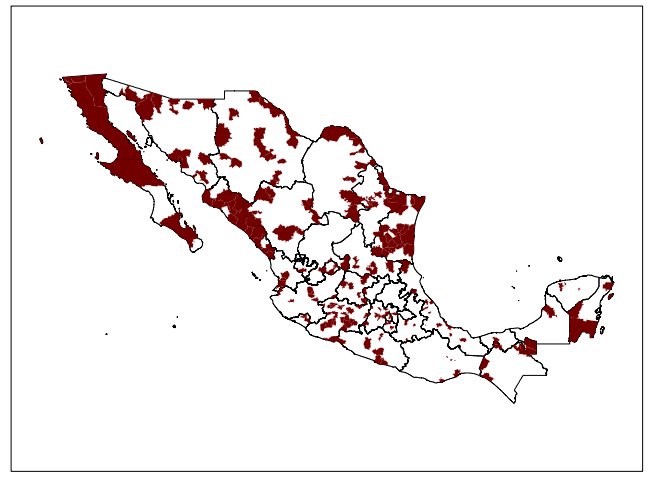

(c) Tijuana DTO

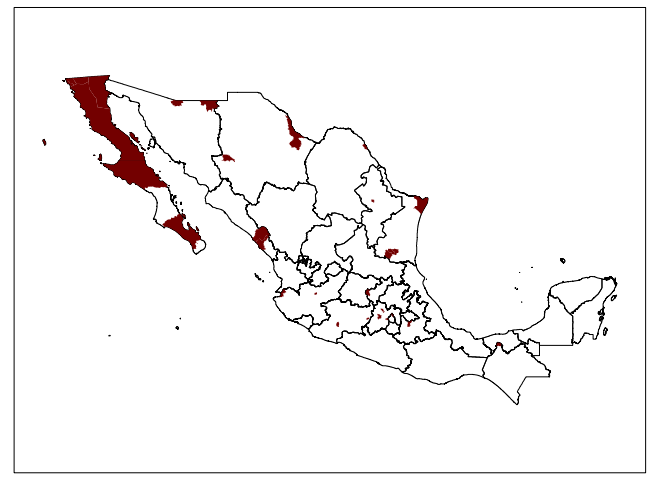

(e) Juárez DTO

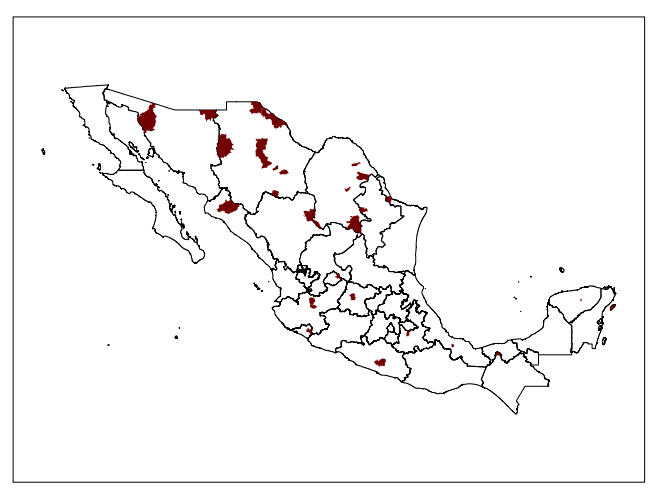

(b) Sinaloa-Beltrán-Leyva DTO

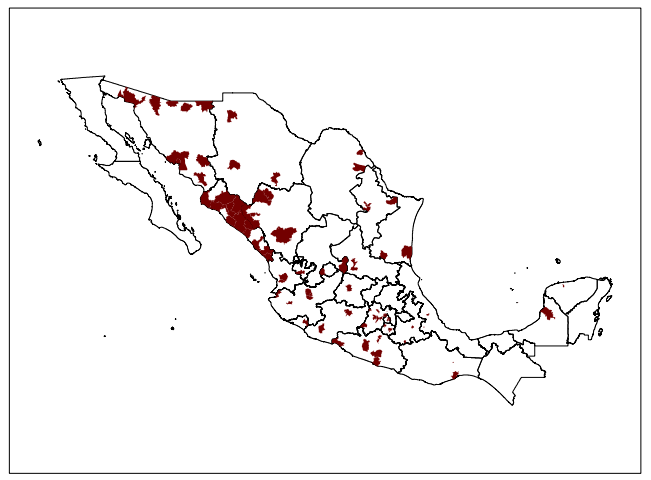

(d) Gulf DTO

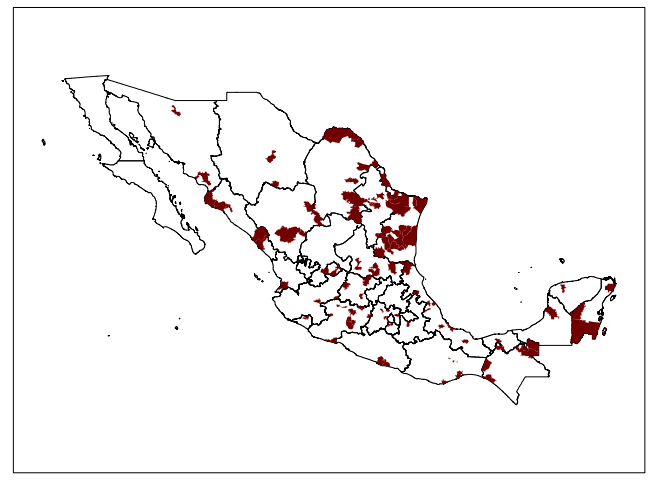

(f) La Familia DTO

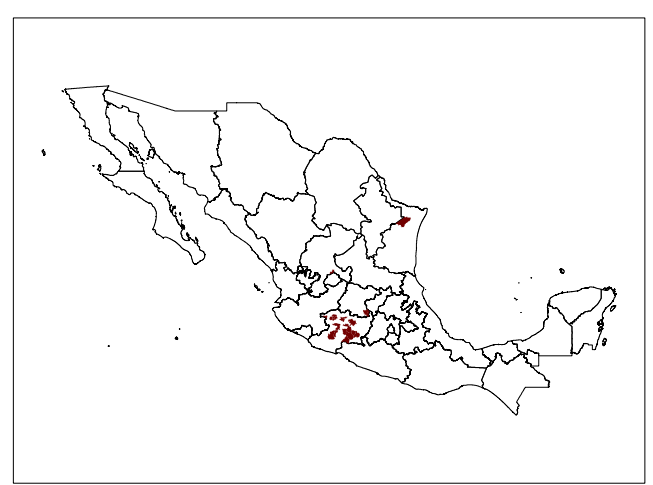

Notes: Each panel shows the municipalities with the specified DTO presence prior to the war on drugs. The areas of operation for each DTO are based on Coscia and Rios (2012). 
Figure 4

Homicide Rates for Municipalities With and Without a DTO Presence

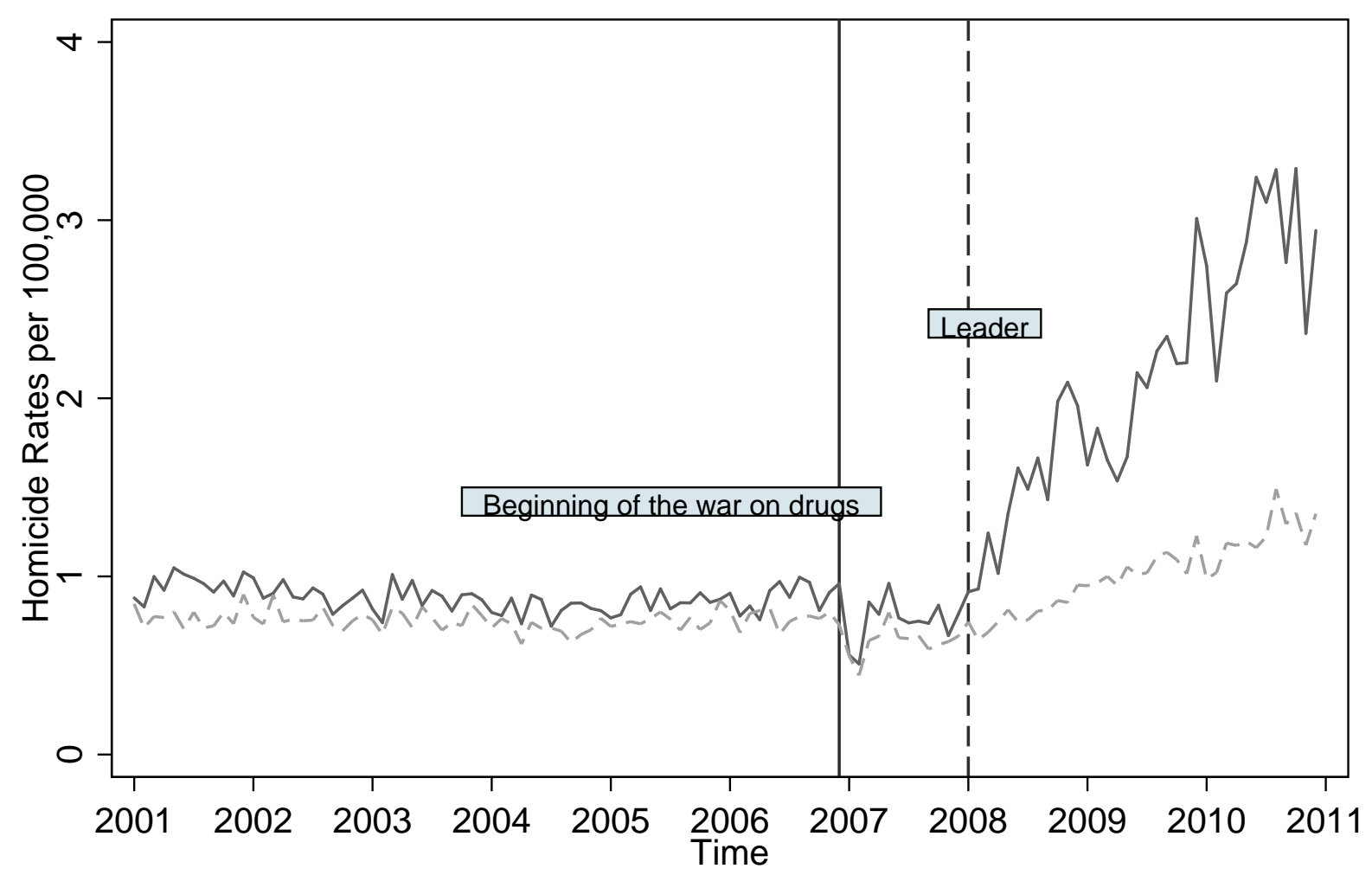

Municipalities w/ DTO Presence $\quad----\cdot$ Municipalities w/ No DTO Presence

Notes: Municipalities with and without a DTO presence prior to the war on drugs are shown in Figure 3. Vertical lines are drawn to highlight the beginning of the war on drugs and the first capture of a DTO leader during the war on drugs. Homicide rates are calculated based on the universe of death certificates from the vital statistics of the National Institute of Statistics and Geography (INEGI) and population counts from the National Council of Population (CONAPO) and El Colegio de México (COLMEX). 
Figure 5

Homicide Rate by DTO Area

(a) Sinaloa-Beltrán-Leyva DTO

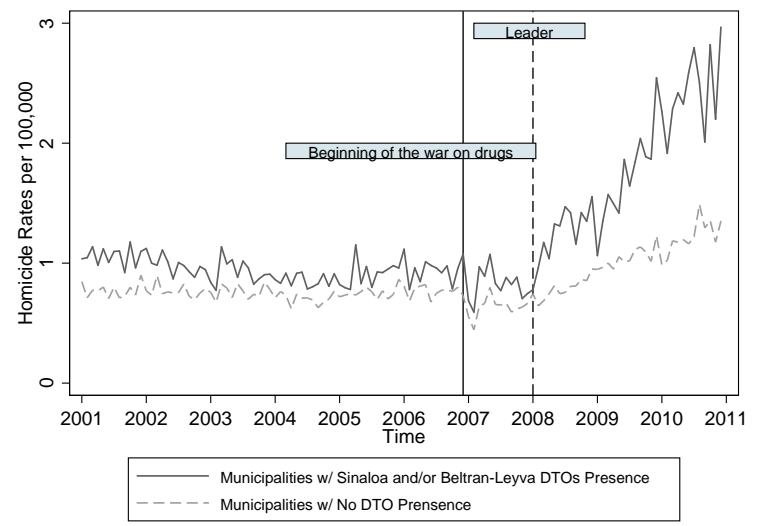

(b) Tijuana DTO

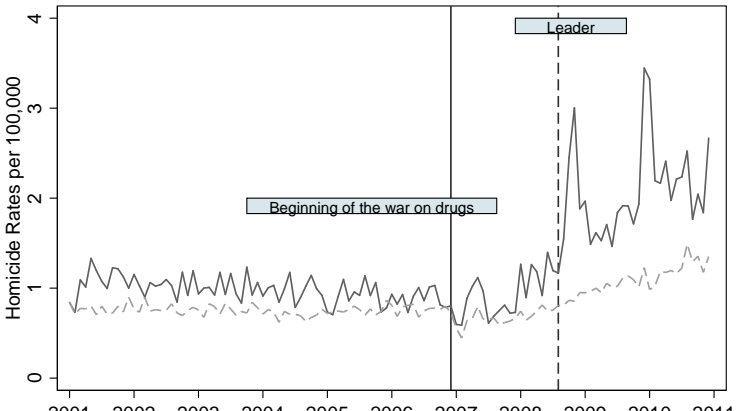

$20012002200320042005 \quad 200620072008200920102011$

- Municipalities $w /$ Tijuana DTO Presence
---- Municipalities w/ No DTO Prensence

(c) Gulf DTO

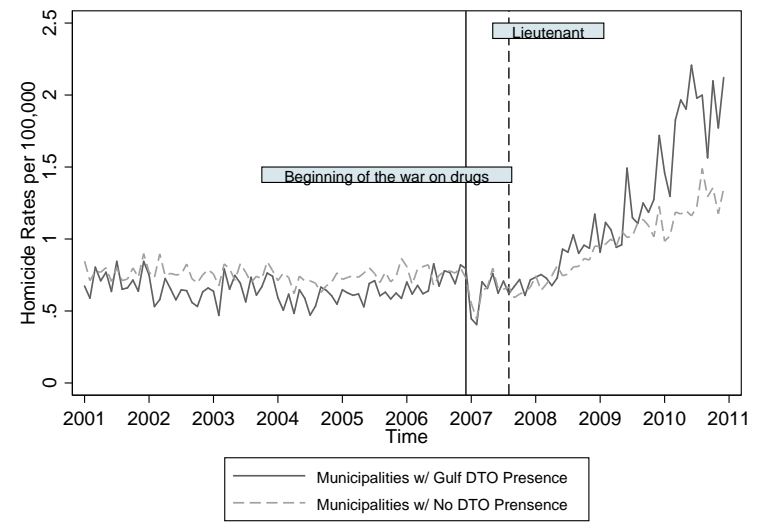

(d) Juárez DTO

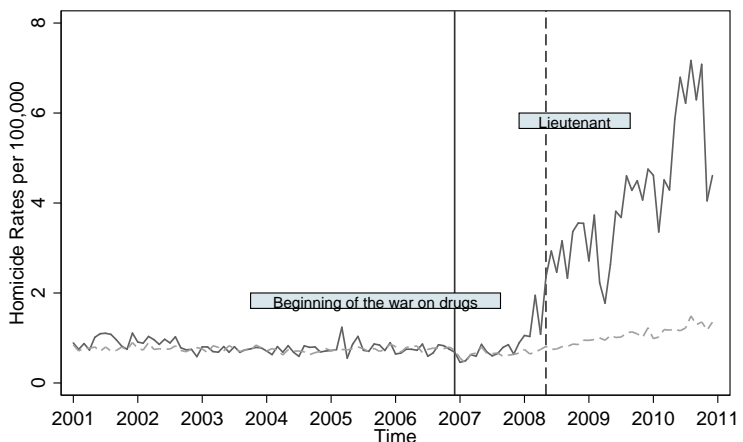

\begin{tabular}{l}
- Municipalities $w /$ Juarez DTO Presence \\
$-\ldots-$ Municipalities w/ No DTO Prensence \\
\hline
\end{tabular} (e) La Familia DTO

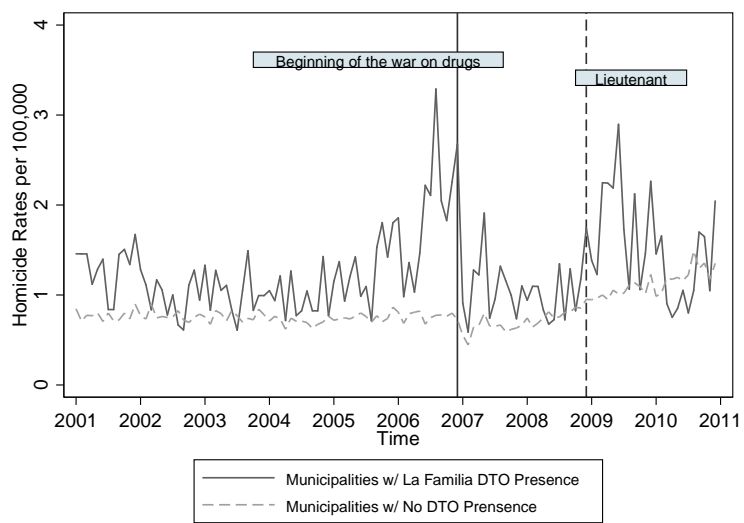

Notes: Municipalities with the specified DTO presence prior to the war on drugs are shown in Figure 3. Vertical lines are drawn to highlight the beginning of the war on drugs and the first capture of a leader or lieutenant from the specified DTO during the war on drugs. Homicide rates are calculated based on the universe of death certificates from the vital statistics of the National Institute of Statistics and Geography (INEGI) and population counts from the National Council of Population (CONAPO) and El Colegio de México (COLMEX). 


\section{Figure 6}

\section{Homicide Rates for Areas Targeted in Major State-Level Operations}

(a) Michoacán Operation

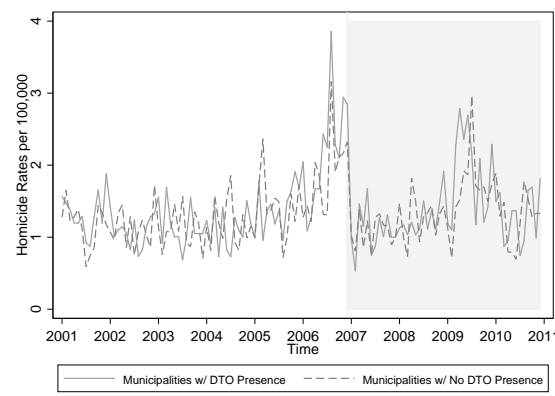

(d) San Luis Potosí Operation

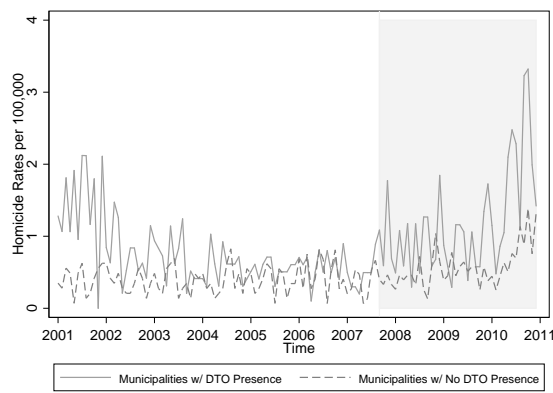

(g) Aguascalientes Operation

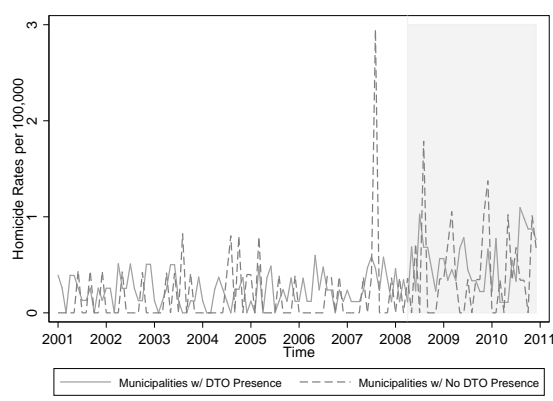

(b) Guerrero Operation

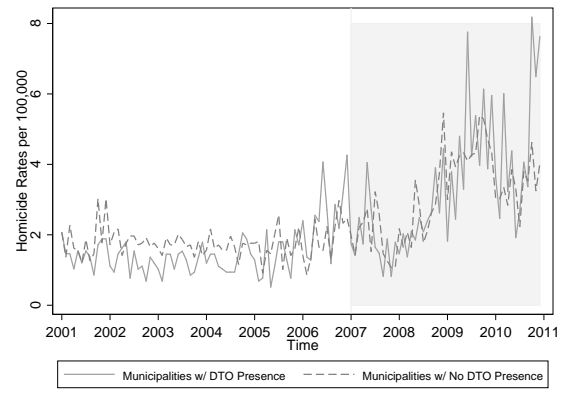

(e) Veracruz Operation

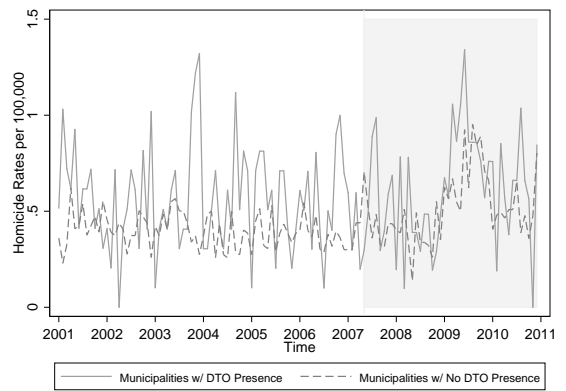

(h) Chihuahua Operation

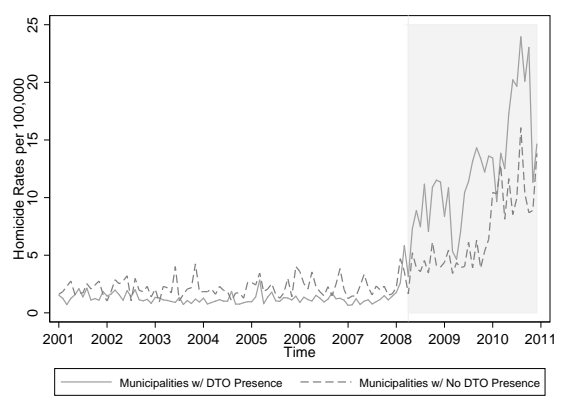

(c) Sierra Madre Operation

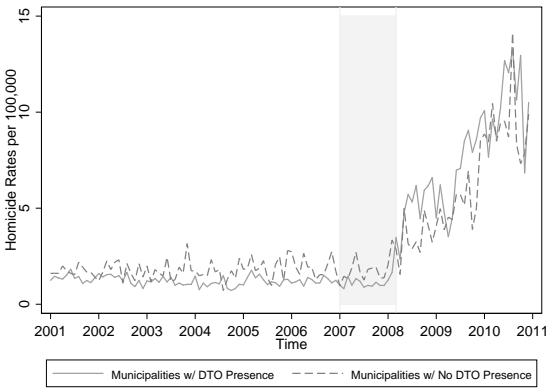

(f) Chiapas Operation

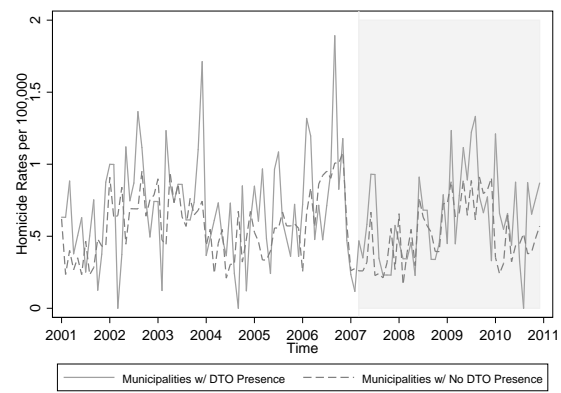

(i) Nuevo León-Tamaulipas Operation

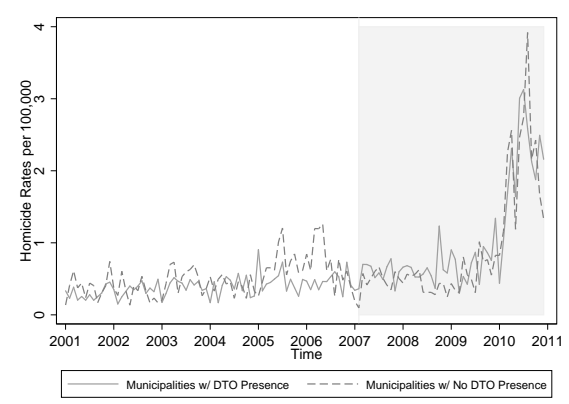

Notes: Each panel shows the homicide rates in the state(s) corresponding to the operation, with separate lines for municipalities with a DTO presence and municipalities without a DTO presence. The shaded region begins when the operation began and ends when the operation ended (where known). Municipalities with and without a DTO presence prior to the war on drugs are shown in Figure 3. Homicide rates are calculated based on the universe of death certificates from the vital statistics of the National Institute of Statistics and Geography (INEGI) and population counts from the National Council of Population (CONAPO) and El Colegio de México (COLMEX). 


\section{Figure 7}

\section{Homicide Rates for Areas Targeted in Major Municipality-Level Operations}

(a) Marlin Operation

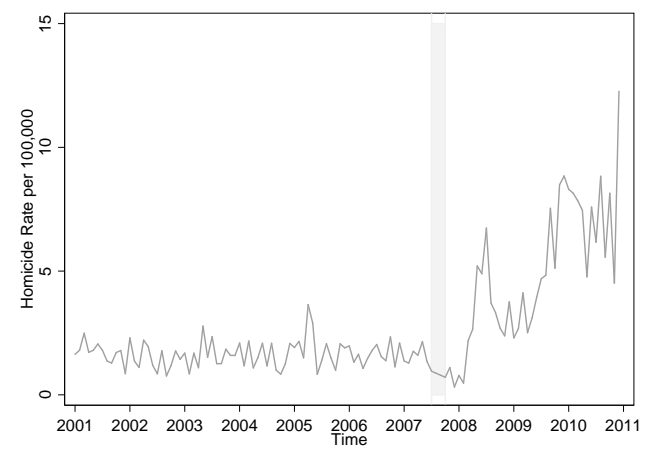

(c) Navolato Operation

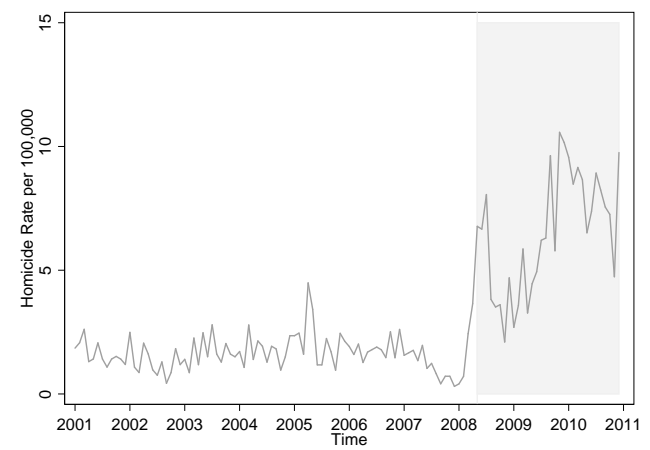

(e) Tijuana Operation

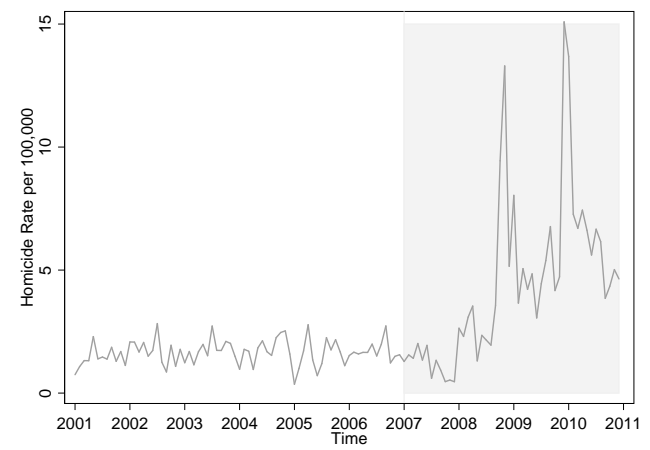

(b) Culiacán Operation

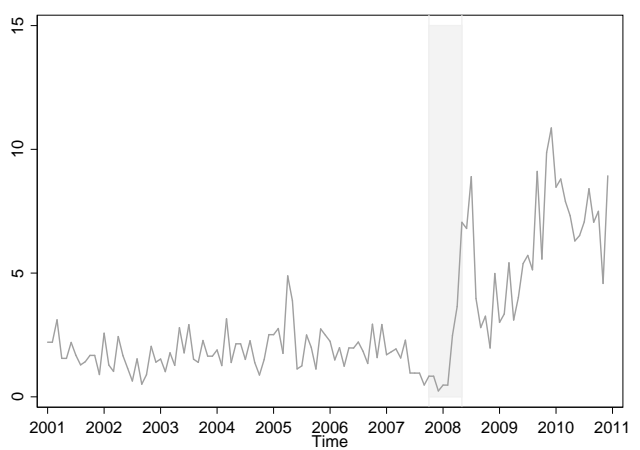

(d) Laguna Segura Operation

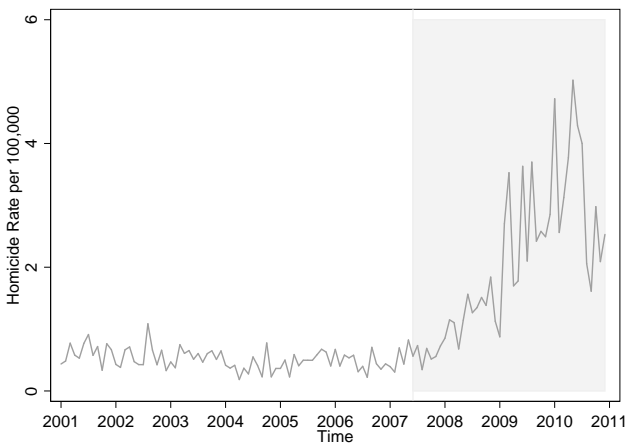

(f) Juárez Operation

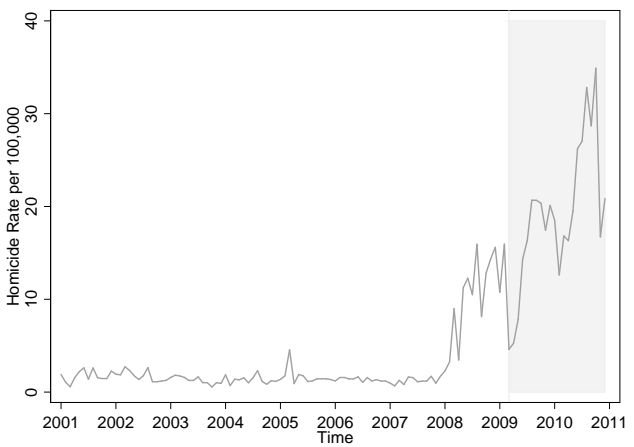

Notes: Each panel shows the homicide rates in the municipality corresponding to the operation. The shaded region begins when the operation began and ends when the operation ended (where known). Municipalities with and without a DTO presence prior to the war on drugs are shown in Figure 3. Homicide rates are calculated based on the universe of death certificates from the vital statistics of the National Institute of Statistics and Geography (INEGI) and population counts from the National Council of Population (CONAPO) and El Colegio de México (COLMEX). 
Table 1

Fist Capture of a Kingpin For Each DTO During War on Drugs

\begin{tabular}{|c|c|c|c|c|c|}
\hline DTO & Name & Position & Date & $\begin{array}{c}\text { Municipalities } \\
\text { w/ DTO } \\
\text { Presence } \\
(2001-2006)\end{array}$ & $\begin{array}{c}\text { Fraction of } \\
\text { Population in } \\
\text { These } \\
\text { Municipalities }\end{array}$ \\
\hline Sinaloa-Beltrán-Leyva & $\begin{array}{c}\text { Alfredo Beltrán } \\
\text { Leyva }\end{array}$ & Leader & $1 / 21 / 08$ & 83 & 0.19 \\
\hline Tijuana & $\begin{array}{c}\text { Eduardo Arellano } \\
\text { Félix }\end{array}$ & Leader & $10 / 25 / 08$ & 31 & 0.10 \\
\hline Gulf & $\begin{array}{l}\text { Juan Carlos de la } \\
\text { Cruz Reyna }\end{array}$ & Lieutenant & $8 / 29 / 07$ & 118 & 0.18 \\
\hline Juárez & $\begin{array}{c}\text { Pedro Sánchez } \\
\text { Arras }\end{array}$ & Lieutenant & $5 / 13 / 08$ & 31 & 0.09 \\
\hline La Familia & $\begin{array}{c}\text { Alberto Espinoza } \\
\text { Barrón }\end{array}$ & Lieutenant & $12 / 29 / 08$ & 22 & 0.02 \\
\hline
\end{tabular}

Notes: Information of first captures is based on a compendium of press releases of the Army (SEDENA), the Navy (SEMAR), and the Office of the Attorney General (PGR). Municipalities with a DTO presence prior to the war on drugs are shown in Figure 3. The proportion of the population is estimated based on population counts from the National Council of Population (CONAPO) and El Colegio de México (COLMEX). 
Table 2

Estimated Effects of Kingpin Captures on Homicides

\begin{tabular}{|c|c|c|c|c|c|}
\hline & $(1)$ & $(2)$ & $(3)$ & $(4)$ & $(5)$ \\
\hline Municipality of capture prior 7 to 12 months & & & & & $\begin{array}{c}-0.021 \\
(0.161)\end{array}$ \\
\hline Municipality of capture prior 1 to 6 months & & & & $\begin{array}{c}-0.066 \\
(0.231)\end{array}$ & $\begin{array}{l}-0.060 \\
(0.230)\end{array}$ \\
\hline Municipality of capture after 0 to 5 months & $\begin{array}{c}0.735^{* * *} \\
(0.250)\end{array}$ & $\begin{array}{c}0.576^{* * *} \\
(0.197)\end{array}$ & $\begin{array}{c}0.586^{* * *} \\
(0.196)\end{array}$ & $\begin{array}{c}0.590^{* * *} \\
(0.215)\end{array}$ & $\begin{array}{c}0.598^{* * *} \\
(0.207)\end{array}$ \\
\hline Municipality of capture after 6 to 11 months & $\begin{array}{c}0.681^{* * *} \\
(0.141)\end{array}$ & $\begin{array}{c}0.486^{* * *} \\
(0.088)\end{array}$ & $\begin{array}{c}0.495^{* * *} \\
(0.090)\end{array}$ & $\begin{array}{c}0.504^{* * *} \\
(0.091)\end{array}$ & $\begin{array}{c}0.512^{* * *} \\
(0.086)\end{array}$ \\
\hline Municipality of capture after 12 or more months & $\begin{array}{c}0.874^{* * * *} \\
(0.322)\end{array}$ & $\begin{array}{c}0.573^{* *} \\
(0.236)\end{array}$ & $\begin{array}{c}0.581^{* *} \\
(0.233)\end{array}$ & $\begin{array}{c}0.590 * * \\
(0.243)\end{array}$ & $\begin{array}{c}0.599 * * \\
(0.233)\end{array}$ \\
\hline Neighbor w/ same DTO prior 7 to 12 months & & & & & $\begin{array}{l}-0.022 \\
(0.096)\end{array}$ \\
\hline Neighbor w/ same DTO prior 1 to 6 months & & & & $\begin{array}{l}-0.023 \\
(0.097)\end{array}$ & $\begin{array}{l}-0.017 \\
(0.102)\end{array}$ \\
\hline Neighbor w/ same DTO after 0 to 5 months & $\begin{array}{c}0.448^{* *} \\
(0.184)\end{array}$ & $\begin{array}{l}0.239^{*} \\
(0.135)\end{array}$ & $\begin{array}{l}0.251^{*} \\
(0.152)\end{array}$ & $\begin{array}{l}0.263^{*} \\
(0.146)\end{array}$ & $\begin{array}{c}0.273^{* *} \\
(0.139)\end{array}$ \\
\hline Neighbor w/ same DTO after 6 to 11 months & $\begin{array}{c}0.375^{* * * *} \\
(0.089)\end{array}$ & $\begin{array}{l}0.147^{*} \\
(0.082)\end{array}$ & $\begin{array}{l}0.157^{*} \\
(0.093)\end{array}$ & $\begin{array}{l}0.173^{*} \\
(0.090)\end{array}$ & $\begin{array}{l}0.183^{*} \\
(0.099)\end{array}$ \\
\hline Neighbor w/ same DTO after 12 or more months & $\begin{array}{c}0.411^{* * *} \\
(0.155)\end{array}$ & $\begin{array}{c}-0.046 \\
(0.073)\end{array}$ & $\begin{array}{l}-0.036 \\
(0.068)\end{array}$ & $\begin{array}{c}-0.020 \\
(0.080)\end{array}$ & $\begin{array}{l}-0.009 \\
(0.089)\end{array}$ \\
\hline Non-neighbor w/ same DTO prior 7 to 12 months & & & & & $\begin{array}{c}0.026 \\
(0.031)\end{array}$ \\
\hline Non-neighbor w/ same DTO prior 1 to 6 months & & & & $\begin{array}{c}0.037 \\
(0.036)\end{array}$ & $\begin{array}{c}0.052 \\
(0.045)\end{array}$ \\
\hline Non-neighbor w/ same DTO after 0 to 5 months & $\begin{array}{l}0.066^{*} \\
(0.040)\end{array}$ & $\begin{array}{c}0.049 \\
(0.037)\end{array}$ & $\begin{array}{c}0.069^{* *} \\
(0.035)\end{array}$ & $\begin{array}{c}0.091^{* *} \\
(0.046)\end{array}$ & $\begin{array}{l}0.105^{*} \\
(0.056)\end{array}$ \\
\hline Non-neighbor w/ same DTO after 6 to 11 months & $\begin{array}{c}0.098 \\
(0.060)\end{array}$ & $\begin{array}{c}0.080 \\
(0.056)\end{array}$ & $\begin{array}{l}0.090^{*} \\
(0.050)\end{array}$ & $\begin{array}{l}0.111^{*} \\
(0.060)\end{array}$ & $\begin{array}{l}0.127^{*} \\
(0.066)\end{array}$ \\
\hline Non-neighbor w/ same DTO after 12 or more months & $\begin{array}{c}0.219^{* * *} \\
(0.078)\end{array}$ & $\begin{array}{c}0.152^{* * *} \\
(0.059)\end{array}$ & $\begin{array}{c}0.162^{* * *} * \\
(0.057)\end{array}$ & $\begin{array}{c}0.184^{* * *} \\
(0.062)\end{array}$ & $\begin{array}{c}0.199^{* * *} * \\
(0.068)\end{array}$ \\
\hline Other Neighbor prior 7 to 12 months & & & & & $\begin{array}{l}0.016 \\
(0.027)\end{array}$ \\
\hline Other Neighbor prior 1 to 6 months & & & & $\begin{array}{c}-0.051 \\
(0.033)\end{array}$ & $\begin{array}{l}-0.047 \\
(0.036)\end{array}$ \\
\hline Other Neighbor after 0 to 5 months & $\begin{array}{c}-0.016 \\
(0.038)\end{array}$ & $\begin{array}{c}-0.049 \\
(0.041)\end{array}$ & $\begin{array}{l}-0.048 \\
(0.042)\end{array}$ & $\begin{array}{c}-0.052 \\
(0.039)\end{array}$ & $\begin{array}{l}-0.048 \\
(0.041)\end{array}$ \\
\hline Other Neighbor after 6 to 11 months & $\begin{array}{c}-0.044 \\
(0.038)\end{array}$ & $\begin{array}{c}-0.104^{* *} \\
(0.043)\end{array}$ & $\begin{array}{c}-0.102^{* *} \\
(0.044)\end{array}$ & $\begin{array}{c}-0.103^{* *} \\
(0.044)\end{array}$ & $\begin{array}{c}-0.100^{* *} \\
(0.045)\end{array}$ \\
\hline Other Neighbor after 12 or more months & $\begin{array}{c}-0.005 \\
(0.028)\end{array}$ & $\begin{array}{l}-0.075 \\
(0.066)\end{array}$ & $\begin{array}{c}-0.073 \\
(0.069)\end{array}$ & $\begin{array}{c}-0.074 \\
(0.071)\end{array}$ & $\begin{array}{c}-0.070 \\
(0.067)\end{array}$ \\
\hline $\mathrm{N}$ & 294480 & 294480 & 294480 & 294480 & 294480 \\
\hline State-by-year fixed effects & no & yes & yes & yes & yes \\
\hline Controls & no & no & yes & yes & yes \\
\hline
\end{tabular}

Notes: All estimates include month-by-year fixed effects and municipality fixed effects. The additional controls for columns 3-5 are indicator variables for 0-5, 6-11, and 12+ months after the beginning of the war for municipalities with DTO presence. Standard-error estimates in parentheses are two-way clustered at the state and DTO-combination levels. Homicide rates are calculated based on the universe of death certificates from the vital statistics of the National Institute of Statistics and Geography (INEGI) and population counts from the National Council of Population (CONAPO) and El Colegio de México (COLMEX). Areas of DTO operation for each DTO are based on Coscia and Rios (2012) as described in the text.

${ }^{*}$ significant at $10 \% ;{ }^{* *}$ significant at $5 \%$; ${ }^{* *}$ significant at $1 \%$. 
Table 3

\section{Estimated Effects on Other Outcomes}

\begin{tabular}{|c|c|c|c|c|}
\hline & $\begin{array}{c}(1) \\
\text { Homicide Male }\end{array}$ & $\begin{array}{c}(2) \\
\text { Homicide Female }\end{array}$ & $\begin{array}{c}(3) \\
\text { Domestic Violence }\end{array}$ & $\begin{array}{c}(4) \\
\text { Baby Deaths }\end{array}$ \\
\hline Municipality of capture after 0 to 5 months & $\begin{array}{c}0.576^{* * *} \\
(0.204)\end{array}$ & $\begin{array}{c}0.193 \\
(0.207)\end{array}$ & $\begin{array}{c}0.127 \\
(0.384)\end{array}$ & $\begin{array}{c}0.027 \\
(0.036)\end{array}$ \\
\hline Municipality of capture after 6 to 11 months & $\begin{array}{c}0.462^{* * *} \\
(0.084)\end{array}$ & $\begin{array}{c}0.275 \\
(0.189)\end{array}$ & $\begin{array}{c}0.170 \\
(0.205)\end{array}$ & $\begin{array}{c}0.017 \\
(0.035)\end{array}$ \\
\hline Municipality of capture after 12 or more months & $\begin{array}{c}0.551^{* *} \\
(0.220)\end{array}$ & $\begin{array}{l}0.372^{*} \\
(0.224)\end{array}$ & $\begin{array}{c}0.077 \\
(0.253)\end{array}$ & $\begin{array}{l}-0.038 \\
(0.032)\end{array}$ \\
\hline Neighbor w/ same DTO after 0 to 5 months & $\begin{array}{c}0.239 \\
(0.164)\end{array}$ & $\begin{array}{c}0.040 \\
(0.042)\end{array}$ & $\begin{array}{l}-0.035 \\
(0.093)\end{array}$ & $\begin{array}{c}0.096^{* *} \\
(0.039)\end{array}$ \\
\hline Neighbor w/ same DTO after 6 to 11 months & $\begin{array}{c}0.111 \\
(0.090)\end{array}$ & $\begin{array}{c}0.001 \\
(0.081)\end{array}$ & $\begin{array}{l}-0.031 \\
(0.078)\end{array}$ & $\begin{array}{c}0.051 \\
(0.052)\end{array}$ \\
\hline Neighbor w/ same DTO after 12 or more months & $\begin{array}{l}-0.097 \\
(0.075)\end{array}$ & $\begin{array}{l}-0.024 \\
(0.070)\end{array}$ & $\begin{array}{l}-0.040 \\
(0.065)\end{array}$ & $\begin{array}{c}0.046 \\
(0.029)\end{array}$ \\
\hline Non-neighbor w/ same DTO after 0 to 5 months & $\begin{array}{c}0.068^{* *} \\
(0.034)\end{array}$ & $\begin{array}{c}0.036^{* *} \\
(0.015)\end{array}$ & $\begin{array}{c}-0.011 \\
(0.035)\end{array}$ & $\begin{array}{l}-0.011 \\
(0.015)\end{array}$ \\
\hline Non-neighbor w/ same DTO after 6 to 11 months & $\begin{array}{c}0.091^{* *} \\
(0.046)\end{array}$ & $\begin{array}{l}0.037^{*} \\
(0.019)\end{array}$ & $\begin{array}{c}0.010 \\
(0.045)\end{array}$ & $\begin{array}{l}-0.027 \\
(0.028)\end{array}$ \\
\hline Non-neighbor w/ same DTO after 12 or more months & $\begin{array}{c}0.156^{* * *} \\
(0.050)\end{array}$ & $\begin{array}{c}0.057^{* * *} \\
(0.016)\end{array}$ & $\begin{array}{l}-0.028 \\
(0.036)\end{array}$ & $\begin{array}{l}-0.017 \\
(0.028)\end{array}$ \\
\hline Other Neighbor after 0 to 5 months & $\begin{array}{l}-0.036 \\
(0.039)\end{array}$ & $\begin{array}{l}-0.006 \\
(0.038)\end{array}$ & $\begin{array}{l}-0.005 \\
(0.051)\end{array}$ & $\begin{array}{l}-0.008 \\
(0.034)\end{array}$ \\
\hline Other Neighbor after 6 to 11 months & $\begin{array}{l}-0.088^{*} \\
(0.047)\end{array}$ & $\begin{array}{l}-0.008 \\
(0.030)\end{array}$ & $\begin{array}{c}0.071 \\
(0.058)\end{array}$ & $\begin{array}{l}-0.060 \\
(0.037)\end{array}$ \\
\hline Other Neighbor after 12 or more months & $\begin{array}{l}-0.047 \\
(0.067)\end{array}$ & $\begin{array}{l}-0.024 \\
(0.032)\end{array}$ & $\begin{array}{c}0.050 \\
(0.052)\end{array}$ & $\begin{array}{l}-0.017 \\
(0.026)\end{array}$ \\
\hline $\mathrm{N}$ & 294480 & 294480 & 235584 & 294357 \\
\hline State-by-year fixed effects & yes & yes & yes & yes \\
\hline Controls & yes & yes & yes & yes \\
\hline
\end{tabular}

Notes: See Table 2.

* significant at $10 \%$; ** significant at $5 \%$; ** significant at $1 \%$ 
Table 4

Estimated Effects on Male Homicide Rates by Age

\begin{tabular}{|c|c|c|c|c|c|c|c|}
\hline Age group: & $\begin{array}{c}(1) \\
0-14\end{array}$ & $\begin{array}{c}(2) \\
15-29\end{array}$ & $\begin{array}{c}(3) \\
30-44\end{array}$ & $\begin{array}{c}(4) \\
45-59\end{array}$ & $\begin{array}{c}(5) \\
60-74\end{array}$ & $\begin{array}{c}(6) \\
75-89\end{array}$ & $\begin{array}{c}(7) \\
90+\end{array}$ \\
\hline Municipality of capture after 0 to 5 months & $\begin{array}{c}0.094 \\
(0.090)\end{array}$ & $\begin{array}{c}0.596^{* * *} \\
(0.208)\end{array}$ & $\begin{array}{c}0.505^{* * *} \\
(0.174)\end{array}$ & $\begin{array}{c}0.227 \\
(0.211)\end{array}$ & $\begin{array}{c}0.094 \\
(0.153)\end{array}$ & $\begin{array}{c}0.021 \\
(0.066)\end{array}$ & $\begin{array}{c}-0.016 \\
(0.046)\end{array}$ \\
\hline Municipality of capture after 6 to 11 months & $\begin{array}{c}0.026 \\
(0.040)\end{array}$ & $\begin{array}{c}0.272 \\
(0.178)\end{array}$ & $\begin{array}{c}0.583^{* * *} \\
(0.132)\end{array}$ & $\begin{array}{c}0.236 \\
(0.172)\end{array}$ & $\begin{array}{l}0.098^{*} \\
(0.056)\end{array}$ & $\begin{array}{l}-0.045 \\
(0.047)\end{array}$ & $\begin{array}{l}-0.018 \\
(0.047)\end{array}$ \\
\hline Municipality of capture after 12 or more months & $\begin{array}{c}0.015 \\
(0.057)\end{array}$ & $\begin{array}{c}0.555^{* *} \\
(0.226)\end{array}$ & $\begin{array}{c}0.568^{* * *} \\
(0.168)\end{array}$ & $\begin{array}{c}0.324 \\
(0.211)\end{array}$ & $\begin{array}{c}0.128 \\
(0.116)\end{array}$ & $\begin{array}{l}-0.048 \\
(0.035)\end{array}$ & $\begin{array}{l}-0.009 \\
(0.044)\end{array}$ \\
\hline Neighbor w/ same DTO after 0 to 5 months & $\begin{array}{c}0.003 \\
(0.021)\end{array}$ & $\begin{array}{c}0.111 \\
(0.138)\end{array}$ & $\begin{array}{c}0.209^{* *} \\
(0.090)\end{array}$ & $\begin{array}{l}-0.011 \\
(0.045)\end{array}$ & $\begin{array}{c}-0.022 \\
(0.030)\end{array}$ & $\begin{array}{c}0.008 \\
(0.018)\end{array}$ & $\begin{array}{c}-0.036^{* *} \\
(0.016)\end{array}$ \\
\hline Neighbor w/ same DTO after 6 to 11 months & $\begin{array}{l}-0.026 \\
(0.053)\end{array}$ & $\begin{array}{c}0.097 \\
(0.091)\end{array}$ & $\begin{array}{l}-0.008 \\
(0.044)\end{array}$ & $\begin{array}{l}-0.043 \\
(0.068)\end{array}$ & $\begin{array}{l}-0.037 \\
(0.065)\end{array}$ & $\begin{array}{c}0.007 \\
(0.022)\end{array}$ & $\begin{array}{l}-0.028 \\
(0.024)\end{array}$ \\
\hline Neighbor w/ same DTO after 12 or more months & $\begin{array}{l}-0.019 \\
(0.038)\end{array}$ & $\begin{array}{l}-0.096 \\
(0.060)\end{array}$ & $\begin{array}{c}-0.081 \\
(0.060)\end{array}$ & $\begin{array}{l}-0.090 \\
(0.103)\end{array}$ & $\begin{array}{c}-0.066 \\
(0.046)\end{array}$ & $\begin{array}{l}-0.023 \\
(0.036)\end{array}$ & $\begin{array}{l}-0.033 \\
(0.027)\end{array}$ \\
\hline Non-neighbor w/ same DTO after 0 to 5 months & $\begin{array}{l}-0.000 \\
(0.008)\end{array}$ & $\begin{array}{c}0.042 \\
(0.029)\end{array}$ & $\begin{array}{c}0.044^{* *} \\
(0.019)\end{array}$ & $\begin{array}{c}0.038 * * \\
(0.015)\end{array}$ & $\begin{array}{c}0.013 \\
(0.013)\end{array}$ & $\begin{array}{c}0.002 \\
(0.010)\end{array}$ & $\begin{array}{c}0.002 \\
(0.008)\end{array}$ \\
\hline Non-neighbor w/ same DTO after 6 to 11 months & $\begin{array}{c}0.001 \\
(0.013)\end{array}$ & $\begin{array}{c}0.062 \\
(0.038)\end{array}$ & $\begin{array}{c}0.061^{* *} \\
(0.029)\end{array}$ & $\begin{array}{c}0.039^{* * *} \\
(0.014)\end{array}$ & $\begin{array}{c}0.001 \\
(0.018)\end{array}$ & $\begin{array}{l}-0.004 \\
(0.014)\end{array}$ & $\begin{array}{l}-0.000 \\
(0.011)\end{array}$ \\
\hline Non-neighbor w/ same DTO after 12 or more months & $\begin{array}{c}0.003 \\
(0.013)\end{array}$ & $\begin{array}{c}0.109^{* *} \\
(0.043)\end{array}$ & $\begin{array}{c}0.123^{* * *} \\
(0.041)\end{array}$ & $\begin{array}{c}0.058^{* * *} \\
(0.016)\end{array}$ & $\begin{array}{c}0.001 \\
(0.016)\end{array}$ & $\begin{array}{l}-0.005 \\
(0.017)\end{array}$ & $\begin{array}{l}-0.012 \\
(0.013)\end{array}$ \\
\hline Other Neighbor after 0 to 5 months & $\begin{array}{c}0.017 \\
(0.015)\end{array}$ & $\begin{array}{c}0.000 \\
(0.026)\end{array}$ & $\begin{array}{l}-0.017 \\
(0.026)\end{array}$ & $\begin{array}{l}-0.011 \\
(0.033)\end{array}$ & $\begin{array}{l}-0.019 \\
(0.025)\end{array}$ & $\begin{array}{l}-0.007 \\
(0.014)\end{array}$ & $\begin{array}{l}-0.006 \\
(0.007)\end{array}$ \\
\hline Other Neighbor after 6 to 11 months & $\begin{array}{c}0.016 \\
(0.016)\end{array}$ & $\begin{array}{l}-0.016 \\
(0.037)\end{array}$ & $\begin{array}{c}-0.049^{* *} \\
(0.023)\end{array}$ & $\begin{array}{l}-0.026 \\
(0.024)\end{array}$ & $\begin{array}{l}-0.005 \\
(0.025)\end{array}$ & $\begin{array}{c}0.002 \\
(0.016)\end{array}$ & $\begin{array}{c}0.001 \\
(0.012)\end{array}$ \\
\hline Other Neighbor after 12 or more months & $\begin{array}{c}0.030^{* *} \\
(0.012)\end{array}$ & $\begin{array}{c}0.004 \\
(0.054)\end{array}$ & $\begin{array}{l}-0.003 \\
(0.038)\end{array}$ & $\begin{array}{l}-0.006 \\
(0.021)\end{array}$ & $\begin{array}{l}-0.008 \\
(0.021)\end{array}$ & $\begin{array}{c}0.005 \\
(0.015)\end{array}$ & $\begin{array}{c}0.009 \\
(0.021)\end{array}$ \\
\hline $\begin{array}{l}\mathrm{N} \\
\text { State-by-year fixed effects } \\
\text { Controls }\end{array}$ & $\begin{array}{l}294480 \\
\text { yes } \\
\text { yes }\end{array}$ & $\begin{array}{l}294480 \\
\text { yes } \\
\text { yes }\end{array}$ & $\begin{array}{l}294480 \\
\text { yes } \\
\text { yes }\end{array}$ & $\begin{array}{l}294429 \\
\text { yes } \\
\text { yes }\end{array}$ & $\begin{array}{l}294480 \\
\text { yes } \\
\text { yes }\end{array}$ & $\begin{array}{l}293938 \\
\text { yes } \\
\text { yes }\end{array}$ & $\begin{array}{l}252559 \\
\text { yes } \\
\text { yes }\end{array}$ \\
\hline
\end{tabular}

Notes: See Table 2.

* significant at $10 \%$; ** significant at $5 \%$; ** significant at $1 \%$ 
Table 5

Sensitivity Analysis for Estimated Effects of Kingpin Captures on Homicides

\begin{tabular}{|c|c|c|c|c|c|c|}
\hline & (1) & (2) & (3) & $(4)$ & (5) & (6) \\
\hline DTO omitted from analysis: & none & $\begin{array}{c}\text { Sinaloa- } \\
\text { Beltrán- } \\
\text { Leyva }\end{array}$ & Tijuana & Gulf & Juárez & Familia \\
\hline Municipality of capture after 0 to 5 months & $\begin{array}{c}0.586^{* * *} \\
(0.196)\end{array}$ & $\begin{array}{c}1.011^{* * *} \\
(0.046)\end{array}$ & $\begin{array}{c}0.476^{* *} \\
(0.237)\end{array}$ & $\begin{array}{c}0.761^{* * *} \\
(0.230)\end{array}$ & $\begin{array}{c}0.477^{* *} \\
(0.224)\end{array}$ & $\begin{array}{c}0.547^{* *} \\
(0.250)\end{array}$ \\
\hline Municipality of capture after 6 to 11 months & $\begin{array}{c}0.495^{* * *} \\
(0.090)\end{array}$ & $\begin{array}{c}0.598^{* * *} \\
(0.059)\end{array}$ & $\begin{array}{c}0.468^{* * *} \\
(0.112)\end{array}$ & $\begin{array}{c}0.672^{* * *} \\
(0.068)\end{array}$ & $\begin{array}{c}0.461^{* * *} \\
(0.111)\end{array}$ & $\begin{array}{c}0.509^{* * *} \\
(0.114)\end{array}$ \\
\hline Municipality of capture after 12 or more months & $\begin{array}{c}0.581^{* *} \\
(0.233)\end{array}$ & $\begin{array}{c}1.178^{* * *} \\
(0.039)\end{array}$ & $\begin{array}{l}0.482^{*} \\
(0.264)\end{array}$ & $\begin{array}{c}1.022^{* * * *} \\
(0.126)\end{array}$ & $\begin{array}{l}0.405^{*} \\
(0.213)\end{array}$ & $\begin{array}{c}0.634^{* *} \\
(0.269)\end{array}$ \\
\hline Neighbor w/ same DTO after 0 to 5 months & $\begin{array}{l}0.251^{*} \\
(0.152)\end{array}$ & $\begin{array}{l}0.356^{*} \\
(0.213)\end{array}$ & $\begin{array}{c}0.128 \\
(0.105)\end{array}$ & $\begin{array}{c}0.356^{* *} \\
(0.156)\end{array}$ & $\begin{array}{c}0.237 \\
(0.159)\end{array}$ & $\begin{array}{c}0.252 \\
(0.174)\end{array}$ \\
\hline Neighbor w/ same DTO after 6 to 11 months & $\begin{array}{l}0.157^{*} \\
(0.093)\end{array}$ & $\begin{array}{c}0.123 \\
(0.114)\end{array}$ & $\begin{array}{c}0.158 \\
(0.110)\end{array}$ & $\begin{array}{c}0.263^{* * *} \\
(0.080)\end{array}$ & $\begin{array}{c}0.138 \\
(0.095)\end{array}$ & $\begin{array}{c}0.150 \\
(0.109)\end{array}$ \\
\hline Neighbor w/ same DTO after 12 or more months & $\begin{array}{l}-0.036 \\
(0.068)\end{array}$ & $\begin{array}{c}-0.007 \\
(0.051)\end{array}$ & $\begin{array}{c}-0.023 \\
(0.073)\end{array}$ & $\begin{array}{c}0.066 \\
(0.082)\end{array}$ & $\begin{array}{l}-0.090 \\
(0.055)\end{array}$ & $\begin{array}{l}-0.024 \\
(0.080)\end{array}$ \\
\hline Non-neighbor w/ same DTO after 0 to 5 months & $\begin{array}{c}0.069^{* *} \\
(0.035)\end{array}$ & $\begin{array}{l}0.063^{*} \\
(0.038)\end{array}$ & $\begin{array}{l}0.082^{*} \\
(0.044)\end{array}$ & $\begin{array}{l}0.103^{*} \\
(0.053)\end{array}$ & $\begin{array}{c}0.047^{* *} \\
(0.023)\end{array}$ & $\begin{array}{l}0.064^{*} \\
(0.033)\end{array}$ \\
\hline Non-neighbor w/ same DTO after 6 to 11 months & $\begin{array}{l}0.090^{*} \\
(0.050)\end{array}$ & $\begin{array}{c}0.051 \\
(0.038)\end{array}$ & $\begin{array}{c}0.101 \\
(0.062)\end{array}$ & $\begin{array}{c}0.149^{* *} \\
(0.076)\end{array}$ & $\begin{array}{l}0.046^{*} \\
(0.028)\end{array}$ & $\begin{array}{l}0.098^{*} \\
(0.055)\end{array}$ \\
\hline Non-neighbor w/ same DTO after 12 or more months & $\begin{array}{c}0.162^{* * *} \\
(0.057)\end{array}$ & $\begin{array}{c}0.109^{* *} \\
(0.043)\end{array}$ & $\begin{array}{c}0.175^{* * *} \\
(0.067)\end{array}$ & $\begin{array}{c}0.235^{* * *} \\
(0.077)\end{array}$ & $\begin{array}{c}0.122^{* * *} \\
(0.036)\end{array}$ & $\begin{array}{c}0.167^{* * *} \\
(0.061)\end{array}$ \\
\hline Other Neighbor after 0 to 5 months & $\begin{array}{l}-0.048 \\
(0.042)\end{array}$ & $\begin{array}{c}-0.029^{*} \\
(0.016)\end{array}$ & $\begin{array}{l}-0.050 \\
(0.041)\end{array}$ & $\begin{array}{c}-0.059^{* *} \\
(0.024)\end{array}$ & $\begin{array}{l}-0.048 \\
(0.036)\end{array}$ & $\begin{array}{l}-0.045 \\
(0.095)\end{array}$ \\
\hline Other Neighbor after 6 to 11 months & $\begin{array}{c}-0.102^{* *} \\
(0.044)\end{array}$ & $\begin{array}{c}-0.102^{* * *} \\
(0.022)\end{array}$ & $\begin{array}{c}-0.106^{* *} \\
(0.047)\end{array}$ & $\begin{array}{c}-0.112^{* * *} \\
(0.026)\end{array}$ & $\begin{array}{c}-0.085^{* *} \\
(0.043)\end{array}$ & $\begin{array}{l}-0.130 \\
(0.093)\end{array}$ \\
\hline Other Neighbor after 12 or more months & $\begin{array}{l}-0.073 \\
(0.069)\end{array}$ & $\begin{array}{c}-0.094^{*} \\
(0.050)\end{array}$ & $\begin{array}{c}-0.077 \\
(0.073)\end{array}$ & $\begin{array}{l}-0.128 \\
(0.083)\end{array}$ & $\begin{array}{l}-0.004 \\
(0.038)\end{array}$ & $\begin{array}{l}-0.115 \\
(0.121)\end{array}$ \\
\hline $\mathrm{N}$ & 294480 & 284520 & 290760 & 279480 & 290040 & 290400 \\
\hline State-by-year fixed effects & yes & yes & yes & yes & yes & yes \\
\hline Controls & yes & yes & yes & yes & yes & yes \\
\hline
\end{tabular}

Notes: See Table 2.

* significant at $10 \% ;{ }^{* *}$ significant at $5 \% ;{ }^{* * *}$ significant at $1 \%$ 